\title{
Upper extremity impairments in type 1 diabetes with long duration: common problems with great impact on daily life
}

Kerstin Gutefeldt, Christina A Hedman, Ingrid S M Thyberg, Margareta BachrachLindström, Hans Arnqvist and Anna Spångeus

The self-archived postprint version of this journal article is available at Linköping University Institutional Repository (DiVA):

http:/ / urn.kb.se/ resolve?urn=urn:nbn:se:liu:diva- 144020

N.B.: When citing this work, cite the original publication.

This is an electronic version of an article published in:

Gutefeldt, K., Hedman, C. A, Thyberg, I. S M, Bachrach-Lindström, M., Arnqvist, H., Spångeus, A., (2017), Upper extremity impairments in type 1 diabetes with long duration: common problems with great impact on daily life, Disability and Rehabilitation, , 1-8.

https:// doi.org/ 10.1080/ 09638288.2017.1397202

Original publication available at:

https:/ / doi.org/ 10.1080/09638288.2017.1397202

Copyright: Taylor \& Francis (STM, Behavioural Science and Public Health Titles)

http:// www.tandf.co.uk/journals/ default.asp 


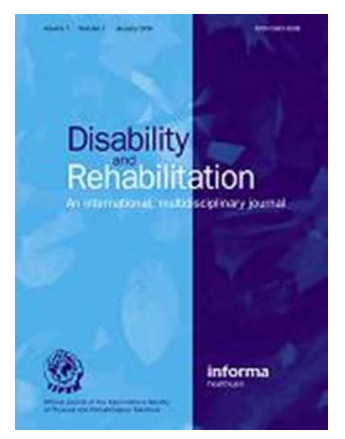

Upper extremity impairments in type 1 diabetes with long duration; common problems with great impact on daily life

\begin{tabular}{|r|l|}
\hline Journal: & Disability and Rehabilitation \\
\hline Manuscript ID & TIDS-03-2017-165.R1 \\
\hline Manuscript Type: & Research Paper \\
\hline Keywords: & $\begin{array}{l}\text { type 1 diabetes, frozen shoulder, carpal tunnel syndrome, Dupuytrens } \\
\text { disease, trigger finger disorder }\end{array}$ \\
\hline
\end{tabular}


Implications for Rehabilitation

*Upper extremity impairments affecting shoulder, hand and fingers are common in patients with type 1 diabetes, the prevalence being 2-4 fold higher compared to nondiabetic persons.

* Patients with diabetes type 1 with upper extremity impairments have more pronounced limitations in daily activities compared to controls with similar impairments.

* Recognizing upper extremity impairments and activity limitations are important in order to improve preventive, therapeutic and rehabilitation methods are needed.

URL: http:/mc.manuscriptcentral.com/dandr Email: davemuller@suffolk.ac.uk 


\title{
Upper extremity impairments in type 1 diabetes with long duration; common problems with great impact on daily life
}

Kerstin Gutefeldt ${ }^{\mathrm{a}}$, Christina A. Hedman ${ }^{\mathrm{a}}$, Ingrid S. M. Thyberg ${ }^{\mathrm{b}}$, Margareta BachrachLindström $^{\mathrm{c}}$, Hans J. Arnqvist ${ }^{\mathrm{d}}$, Anna Spångeus ${ }^{\mathrm{a}, *}$

\begin{abstract}
${ }^{\mathrm{a}}$ Department of Endocrinology and Department of Medical and Health Sciences, Linköping University, Linköping, Sweden; ${ }^{b}$ Department of Rheumatology and Department of Clinical and Experimental Medicine, Linköping University, Linköping, Sweden; ${ }^{\mathrm{c} D i v i s i o n ~ o f ~ N u r s i n g ~}$ Sciences, Department of Medical and Health Sciences, Linköping University, Linköping, Sweden; ${ }^{\mathrm{d} D e p a r t m e n t ~ o f ~ E n d o c r i n o l o g y ~ a n d ~ D e p a r t m e n t ~ o f ~ C l i n i c a l ~ a n d ~ E x p e r i m e n t a l ~}$ Medicine, Linköping University, Linköping, Sweden.
\end{abstract}

${ }^{*}$ Corresponding author: Anna Spångeus
Dept. of Endocrinology/Medical and Health Sciences

Linköping University

S 58183 Linköping, Sweden

Phone: +46-(0)13 286788, E-mail: anna.spangeus@liu.se 


\section{Abstract \\ Purpose}

To investigate the prevalence, activity limitations and potential risk factors of upper extremity impairments in type 1 diabetes in comparison to controls.

\section{Methods}

In a cross-sectional population based study in southeast of Sweden, patients with type 1 diabetes $<35$ years at onset, duration $\geq 20$ years, $<67$ years old and matched controls were invited to answer a questionnaire on upper extremity impairments and activity limitations and to take blood samples.

\section{Results}

773 patients (ages $50 \pm 10$ years, diabetes duration $35 \pm 10$ years) and 708 controls (ages $54 \pm 9$ years) were included. Shoulder pain and stiffness, hand paraesthesia and finger impairments were common in patients with a prevalence of $28-48 \%$, which was $2-4$ folds higher than in controls. Compared to controls, the patients had more bilateral impairments, often had coexistence of several upper extremity impairments, and in the presence of impairments, reported more pronounced activity limitations. Female gender (1.72(1.0662.272), $\mathrm{p}=0.014)$, longer duration (1.046(1.015-1.077), $\mathrm{p}=0.003)$, higher body mass index $(1.08(1.017-1.147), \mathrm{p}=0.013)$ and HbA1c $(1.029(1.008-1.05), \mathrm{p}=0.007)$ were associated with upper extremity impairments.

\section{Conclusion}

Compared to controls, patients with type 1 diabetes have a high prevalence of upper extremity impairments, often bilateral, which are strongly associated with activity limitations. Recognising these in clinical practice is crucial, and improved preventative, therapeutic and rehabilitative interventions are needed. 


\begin{abstract}
Keywords: type 1 diabetes; frozen shoulder; carpal tunnel syndrome; trigger finger disorder; Dupuytren's disease
\end{abstract}




\section{Introduction}

Upper extremity impairments such as flexor tenosynovitis (trigger finger), carpal tunnel syndrome, Dupuytren's disease, frozen shoulder and limited joint mobility are common in patients with diabetes [1-6]. These conditions cause painful and disabling limitations in daily life [7-9], and the efficacy of treatments used in clinical practice is often insufficient [10]. The pathophysiology of these complications remains largely obscure. Increasing age and longer diabetes duration are previously reported as risk factors for musculoskeletal complications in the upper extremity of patients with type 1 and type 2 diabetes $[1,7,9]$. Associations of connective tissue disorders with micro- and macrovascular complications as well as neuropathy have been reported [1,2]. It has been difficult to show a consistent association with HbA1c levels, which is why the role of glycaemic control remains controversial [11-13]. Whether inflammation is involved in these complications is unclear. The accumulation of advanced glycosylation end products (AGE products), which is a crosslink structure, has been proposed as a likely common pathogenic mechanism for the diverse complications [14,15]. Cutaneous fluorescence, indicating AGE products, was recently found in patients with type 1 diabetes with connective tissue problems [1]. The majority of earlier studies were performed on patient samples of 100 to 200 individuals and included patients with both type 1 and type 2 diabetes [2,4,7-9]. One exception is the study by Larkin et al on a large cohort of patients with type 1 diabetes with 1217 participants from the Diabetes Control and Complications Trial/Epidemiology of Diabetes Interventions and Complications (DCCT/EDIC) cohort; however, the study was not population-based [1]. To the best of our knowledge, there are no population-based estimates with matched control groups demonstrating upper extremity impairments in patients with type 1 diabetes. The life expectancy of patients with type 1 diabetes has increased [16], which may result in an 
increased prevalence of upper extremity impairments in this patient group as duration and age are anticipated to be risk factors.

Thus, the aim of the current study was to conduct, to the best of our knowledge, the first cross-sectional, large population-based case-control study to describe the prevalence of upper extremity impairments in patients with type 1 diabetes of long duration ( $\geq 20$ years) compared to a matched control group and to evaluate their association with activities in daily life. Furthermore, likely risk factors for upper extremity impairments were examined.

\section{Materials and methods}

\section{Design and inclusion}

This cross-sectional, case-control study was conducted in cooperation with all nine hospitals in the southeast region in Sweden between 2010 and 2013. Using the hospitals' local diabetes registers, all patients in the region with type 1 diabetes who were diagnosed before the age of 35 years, were not older than 67 years, and had a diabetes duration of $\geq 20$ years were invited to participate in the study. Invitation was conducted by a postal letter with a questionnaire enclosed. The controls, matched for sex and age ( \pm 5 years), were selected from the Swedish population register and were invited when the respective patients were included in the study. All study subjects were asked to take blood samples. The controls were excluded if their selfreported diabetes history or if their laboratory tests showed elevated fasting plasma glucose levels of $\geq 7.0 \mathrm{mmol} / \mathrm{l}$.

Of all the patients invited to participate in the study ( $\mathrm{n}=1727), 773$ accepted participation and were included. Of a total of 721 matched controls who accepted ( $\mathrm{n}=1995$ invited), 13 were excluded because of fasting plasma glucose levels of $\geq 7.0 \mathrm{mmol} / \mathrm{l}$, thus leaving a final total of 


\begin{abstract}
708 controls in the study. The analysis of drop-out patients showed that the drop-outs were significantly younger $(46 \pm 10$ years vs $50 \pm 10$ years, p-value $<0.001)$ and demonstrated a higher proportion of males (i.e., $60 \%$ males in drop-outs vs $45 \%$ males in participants, p-value $<0.001)$. No analysis of drop-out was made in the controls.
\end{abstract}

All participants were asked to take fasting blood samples and were also reminded if not, finally ending up with blood samples available in 603 (78\%) patients and in 531 (75\%) controls. All patients were treated with either multiple insulin injections (MDI) or subcutaneous insulin infusions via an insulin pump (CSII).

An informed signed consent form was obtained from all of the participants. The Research Ethics Committee of the Faculty of Health Sciences, Linköping University, approved the study (M245-09:2010-03-17).

\title{
Assessment and laboratory methods
}

The self-administered questionnaire sent to the patients and controls were identical except for the diabetes-specific questions that were excluded in the control version of the questionnaire (supplementary material).

The first part of the questionnaire, which was constructed from our group, focused on background data including medical history (including co-morbidities such as coeliac disease and previous cardiovascular events), demographic data, smoking habits, occupation, current sick leave, physical activity and questions on diabetic complications. This part also included questions regarding upper extremity impairments and previous surgery for carpal tunnel syndrome or trigger finger. By combing the symptoms shoulder pain and stiffness, we made a proxy variable called "shoulder impairment" which is suggestive of frozen shoulder (adhesive capsulitis). In the analysis, a variable for cardiovascular disease (CVD) was created and was 
defined as individuals with previous myocardial infarction, stroke and angina pectoris. Smoking was defined as individuals with ongoing smoking.

In the second part of the questionnaire, difficulties to perform daily activities were reported by a previously validated tool, Health Assessment Questionnaire (HAQ) [17]. HAQ is often used for patients with rheumatoid arthritis (RA), but it has also been used in several other rheumatic as well as non-rheumatic settings, including diabetes $[11,18,19]$. HAQ is composed of 20 questions in eight categories, describing the subjects' subjective degree of activity limitation based on their experiences in the most recent 7 days. Answers are given in a range from 0 to 3 (where 0 is without any difficulty and 3 is unable to do an activity). The HAQ score is calculated as the mean value of the highest score within each of the eight categories.

All participants were asked to take a blood sample at their local hospital. Blood samplings were performed by venipuncture after an overnight fast and were analysed as routine measurements at the Department of Clinical Chemistry, Linköping University Hospital. The laboratory is accredited by SWEDAC (Swedish Board for Accreditation and Conformity Assessment). High sensitivity C-reactive protein (hsCRP) was analysed using an Advia 1800 instrument (Siemens Healthcare Diagnostics, Deerfield, IL, USA) and a latex-enhanced immunochemistry method with reagents from the same company. The detection limit was 0.3 $\mathrm{mg} / \mathrm{L}$. Creatinine was measured in plasma samples from all patients using a standardised method (Advia 1800, Siemens Healthcare Diagnostics, Deerfield, IL, USA). The method was based on Jaffe reagent and contained a rate-blanking measurement to compensate for interference from bilirubin and a correction for intercept due to pseudocreatinines. An estimated glomerular filtration rate (GFR) was calculated based on the creatinine level using the CKD-EDI formula [20]. Plasma glucose was analysed using an Advia 1200 instrument (Siemens Healthcare Diagnostics, Deerfield, IL, USA). HbA1c was analysed using a TOSOH G7 automated haemoglobin analyser (Tosoh Bioscience, Tokyo, Japan). The same blood 
analyses were performed for patients and controls, except for HbA1c, which was analysed only in patients with diabetes.

\section{Statistics}

The mean and standard deviation or median values and interquartile range are reported for continuous variables with the exception of the HAQ score, which was expressed as the mean and standard error of the mean. The hsCRP values demonstrated skewed distribution and were thus log transformed before statistical evaluation. Numbers and percentages are reported for categorical variables.

For continuous variables, Student's $t$-test was performed when comparing two groups and ANOVA using Bonferroni as post hoc test if there were three or more groups. The $\chi^{2}$ test was used for categorical variables. The univariate and multiple logistic regression models were used to investigate the association of upper extremity impairments and risk factors, including known diabetes complications. In the multivariate analysis model, all risk factors were included (independent) and the different impairments were set as dependent. All statistical tests were performed at the 5\% significance level. Statistics were calculated using SPSS 23.0 for Windows software (IBM Statistics, New York, USA).

\section{Results}

\section{Clinical characteristics}

The characteristics of the patients and controls are shown in table 1. The controls were older than the patients, $54 \pm 9$ vs $50 \pm 10$ years $(\mathrm{p}<0.001)$ and had a higher proportion of females ( $61 \%$ in controls vs $55 \%$ in patients, $\mathrm{p}=0.013)$. There were no differences regarding body mass index (BMI), smoking habits or physically demanding occupation. The patients showed a significantly higher co-morbidity with respect to CVD as well as coeliac disease. 
There was no significant difference in HbAlc levels between the male and female patients, $8.0 \pm 0.9 \%$ vs $8.1 \pm 1.1 \%(63.7 \pm 10.2 \mathrm{mmol} / \mathrm{mol}$ vs $65.3 \pm 12.1 \mathrm{mmol} / \mathrm{mol} ; \mathrm{p}=0.08)$. However, the patients who had previously received laser treatment for retinopathy had higher HbAlc values than the other patients, $8.3 \pm 1.1 \%(67 \pm 12 \mathrm{mmol} / \mathrm{mol})$ vs $7.9 \pm 0.9 \%(63 \pm 10 \mathrm{mmol} / \mathrm{mol})$; $\mathrm{p}<0.001$, respectively. The patients had a slightly higher hsCRP and lower GFR values than the controls, as shown in Table 1.

\section{Upper extremity impairments}

Impairments in shoulders, hands and fingers are shown in Figure 1. Hand paraesthesia (paraesthesia or wakening with numbness in hands and fingers at night) was present in $48 \%$ of the patients compared to $28 \%$ of the controls ( $p<0.001$ ), thus being the most frequent upper limb symptom, followed by shoulder pain and stiffness observed in $38 \%$ of the patients and $18 \%$ of the controls $(\mathrm{p}<0.001)$.

Finger locking, a symptom suggestive of trigger finger, was nearly 3 -fold more common in patients $(31 \%)$ than in controls $(12 \%)$, and the difference was even greater when looking at prior surgery for trigger finger, which was rare in controls with a prevalence of $1 \%$, while $22 \%$ of the patients had undergone surgery. Flexed finger (i.e., inability to fully extend the fingers, suggestive of Dupuytren's contracture and limited joint mobility) was 4-fold more common in patients than in controls, i.e., $28 \% \mathrm{vs} 7 \%$; $\mathrm{p}<0.001$. The absence of all 5 upper extremity impairments or previous surgeries were reported by $21 \%$ of the patients vs $56 \%$ of the controls $(p<0.001)$. Eleven percent of the patients vs $2 \%$ of the controls who had previously undergone surgery for carpal tunnel syndrome still reported hand paraesthesia in the surgically treated hand. Similarly, $9 \%$ of the patients and $0.1 \%$ of the controls who were previously surgically treated for trigger finger still experienced problems with finger locking in the same hand. 
As shown in Figure 1, the prevalence of bilateral impairments from shoulders, hands and fingers were also more common in patients compared to controls. Thus, the patients more frequently had bilateral hand paraesthesia $(75 \%$ bilateral in patients vs $67 \%$ in controls, $\mathrm{p}=0.05)$, hand stiffness ( $81 \%$ bilateral in patients vs $65 \%$ in controls, $\mathrm{p}=0.002)$ and finger locking ( $53 \%$ bilateral in patients vs $34 \%$ in controls, $\mathrm{p}=0.004)$. Furthermore, a borderline significance was noted regarding flexed finger (54\% bilateral in patients vs $39 \%$ in controls, $\mathrm{p}=0.08)$ and previous surgery for carpal tunnel syndrome (60\% bilateral in patients vs $43 \%$ in controls, $\mathrm{p}=0.09$ ). None of the impairments had higher bilateral frequency in the controls than in the patients.

Furthermore, the patients more often experienced coexisting shoulder, hand and finger impairments compared to the controls, as shown in Figure 2. Thus, only $1.3 \%$ of the controls described the coexistence of all five impairments compared with $6.1 \%$ of the patients.

Regarding gender difference, all impairments and the two surgical procedures were more common in female patients than in male patients (although there was only borderline significance regarding flexed finger, i.e. $25 \%$ of males and $31 \%$ of females, $p=0.063$, the others showed significant differences; see supplementary material, figure s1). The controls exhibited a similar pattern with a higher prevalence in females, except for finger impairments and previous trigger finger surgery, which demonstrated no significant difference.

\section{Activity limitations}

As shown in Table 1, the patients reported more difficulties in daily activities (i.e., a higher HAQ score $)$ than the controls $(0.27 \pm 0.02$ vs $0.11 \pm 0.01, \mathrm{p}<0.001)$ when looking at the entire cohort. However, no difference was observed comparing the subjects without any of the five 
impairments in shoulder, hand and finger or previous surgery for carpal tunnel syndrome and trigger finger (patients, $0.05 \pm 0.02$ vs controls, $0.03 \pm 0.01, \mathrm{p}=0.193$ ). In general, females reported higher HAQ scores than males both regarding patients $(0.35 \pm 0.02$ vs $0.18 \pm 02$, $\mathrm{p}<0.001)$ and controls $(0.13 \pm 0.01$ vs $0.08 \pm 0.01, \mathrm{p}=0.048)$.

The HAQ scores in relation to impairments in shoulder, hand and finger are shown in Figure 3. The highest HAQ score was observed in patients experiencing hand stiffness, i.e., HAQ score, $0.52 \pm 0.03)$. The presence of upper extremity impairments yielded higher HAQ scores in patients than in controls, which were significant for all but flexed finger, as shown in Figure 3.

The patients with previous surgery for carpal tunnel syndrome and trigger finger still reported a high HAQ score $(0.45 \pm 0.04$ and $0.44 \pm 0.04$, respectively), which is in contrast to that found in controls, who reported a low HAQ score $(0.09 \pm 0.03$ and $0.11 \pm 0.11$, respectively).

The occurrence of one or more of the five impairments in the same individual and the associated HAQ score are shown in Figure 4 for patients and in the supplementary material (figure s2) for controls. The HAQ score increased with each added coexisting impairment in patients. Thus, patients reporting five impairments had the highest HAQ score $(0.73 \pm 0.07)$, which also tended to be higher than in controls with 5 impairments $(0.40 \pm 0.18, \mathrm{p}=0.084)$. However, the groups were small ( $\mathrm{n}=45$ and 9 , respectively).

\section{Risk factors for upper extremity impairments}

In a multivariate logistic regression, the putative risk factors were tested for association with each of the five impairments separately (Table 2) as well as with a proxy variable for any of the five impairments (i.e., the presence of one or more impairments). The risk of having any of the impairments was significantly associated with gender, where female patients had a 
higher risk $(1.72(1.066-2.272), \mathrm{p}=0.014)$, increased diabetes duration $(1.046(1.015-1.077)$, $\mathrm{p}=0.003)$, increased BMI (1.08 (1.017-1.147), $\mathrm{p}=0.013)$ and increased HbA1c $(1.029$ $(1.008-1.05), \mathrm{p}=0.007)$.

As shown in Table 2, the females were at a higher risk of having all of the separate impairments, except for flexed finger, which seemed to be gender neutral. A similar observation was made in the controls where both finger locking and flexed finger were gender neutral (supplementary material, table s1).

A longer diabetes duration was associated with an increased risk of shoulder impairment and flexed finger. Glycaemic control, assessed by an $\mathrm{HbA1c}$, was associated with shoulder impairment but none of the other investigated impairments. Coeliac disease was strongly associated with a higher risk of hand paraesthesia and hand stiffness.

The presence of any of the finger impairments, i.e. finger locking or flexed finger, was associated with an increased inflammatory activity and showed a borderline association with cardiovascular co-morbidity. In the controls, however, there was no association with inflammation (Table s1).

Smoking, a common risk factor for many diseases, did not show any significant association with any of the investigated upper extremity impairments (although there was borderline significance regarding shoulder impairment) in the patients. This finding is in contrast to the results in the controls, where we found an increased risk for all upper extremity impairments, except for hand paraesthesia (and borderline significance for finger locking, 1.945 (0.9523.972), $\mathrm{p}=0.068)$.

\section{Discussion}

In this large cross-sectional, case-control study of upper extremity impairments in patients with type 1 diabetes, the prevalence of shoulder, hand and finger impairments was 2-4 times as high as that in controls without diabetes and was more commonly bilateral and coexisting 
with other upper extremity impairments. Furthermore, diabetes patients with these impairments reported a greater impact on daily life activities than controls with comparable impairments. Female gender, longer diabetes duration and higher HbA1c levels were all factors that increased the risk of having one or more of the upper extremity impairments. Additional new observations are that BMI was associated with upper extremity impairments and that the presence of coeliac disease seems to be associated with a higher prevalence of hand paraesthesia and hand stiffness. Furthermore, the data indicated a possible role for inflammation in finger complications.

\section{Prevalence of upper extremity impairments}

Facing the limitations of using self-reported symptoms and difficulties in getting specific diagnoses from these, we tried to make a proxy variable (shoulder impairment) for frozen shoulder (adhesive capsulitis) by combining shoulder pain and stiffness [2,3,21]. The shoulder impairment variable was reported in $38 \%$ of the patients. This finding is consistent with the recently published report on musculoskeletal complications in the DCCT/EDIC cohort with patients' characteristics similar to the present study, i.e., a mean age of $52.2 \pm 6.9$ years vs $50.3 \pm 9.6$ years and diabetes duration of $31.1 \pm 4.9$ years vs $35.1 \pm 9.5$ years [1], where adhesive capsulitis was found in $31 \%$ of the patients. In other reports on younger patients with type 1 diabetes with a duration of about 20 years, the prevalence of adhesive capsulitis was $10 \%$ to $16 \%[2,11,21]$. Shoulder pain is common in the general population with a reported prevalence of $7 \%$ to $27 \%$ [22], while the prevalence of adhesive capsulitis has been estimated to be $2 \%$ to $5 \%[3,22]$. In our study, shoulder impairment, as suggestive of adhesive capsulitis, had a prevalence as high as $18 \%$ in the control group why it is conceivable that the questions we used for this condition is somewhat unspecific, but nevertheless highlights a high prevalence of shoulder impairments in patients, in part explained by frozen shoulder, and that these impairments were more prevalent in patients with diabetes than in controls.

Previous surgery for carpal tunnel syndrome or trigger finger was reported by $26 \%$ and $22 \%$ of the patients, respectively, being five and twenty times more common among patients with 
type 1 diabetes than among the controls. Problems with locked finger, suggestive of trigger finger, were reported in $31 \%$ of patients, nearly 3 times higher than in controls. In accordance with our study, the DCCT/EDIC cohort showed that carpal tunnel syndrome and trigger finger were reported in $30 \%$ and $28 \%$ of the patients, respectively [1]. When looking at the patients who had previously undergone surgery for carpal tunnel syndrome, $11 \%$ of the patients still reported hand paraesthesia in the surgically treated hand. Regarding the patients who were previously surgically treated for trigger finger, $9 \%$ still reported problems with finger locking. Corresponding figures for controls were $2 \%$ and $0.1 \%$, respectively.

The results of our comparably large study with a matched control group aiming to visualise diabetes-specific findings are consistent with the DCCT/EDIC cohort and with previous smaller studies showing an excess of connective tissue problems in the upper limb of patients with type 1 diabetes $[1,2,4,7,8]$.

\section{Activity limitations}

As assessed by HAQ, the patients with diabetes reported no activity limitation compared to the controls with the absence of any upper extremity impairments (figure 3). However, each impairment caused more activity limitations in patients compared to controls. With an increasing number of impairments, the HAQ score increased with the exception of the presence of four and five impairments in controls; the latter, however, included few observations. In the DCCT/EDIC study, Larkin et al [1] used Disabilities of the Arm, Shoulder and Hand (DASH) functional disability scores to investigate function and found that the disability scores worsened with the number of symptoms and with the female gender. No comparison was made with a control group without diabetes. Similarly, in a smaller study, Ramchurn et al [11] found additive effects on disability scores (assessed by HAQ) with an 
increasing number of connective tissue symptoms. Regarding gender differences, in addition to the DCCT/EDIC study [1], a smaller study by Redmond et al [23], comparing the functional impairment by trigger finger, carpal tunnel syndrome, Dupuytren's disease and limited joint mobility, showed that women had higher disability scores than men as assessed using DASH. These gender differences might, at least in part, be due to less body strength in women, and thus, a smaller decline in strength, due to different impairments, could have a higher impact on daily life activities that require a greater capacity in women than in men [23]. A similar observation was made in patients with rheumatoid arthritis, where women had a higher HAQ score compared to men, but this was highly dependent on grip strength differences between genders [24].

An interesting finding in the present study was that patients showed a much higher HAQ score than controls after surgery for carpal tunnel syndrome and trigger finger. One could argue that carpal tunnel syndrome is different in patients, being more a sign of neuropathy as well as more of a challenge for the surgeon, as is strengthened by the observation that 5 times more patients than controls remain symptomatic after surgery, as discussed earlier. However, it might also be that other co-morbidities in these groups contributed to our findings.

\section{Risk factors}

Using logistic regression of overall risk factors for the presence of any upper extremity impairment, the present study found that female gender and a longer diabetes duration were significantly associated with a higher risk, consistent with outcomes in previous studies [1,2]. Additionally, significant associations were observed for BMI and HbAlc. When looking at the separate impairments, however, only hand paraesthesia and shoulder impairments were associated with BMI, and shoulder impairments were associated with $\mathrm{HbA1c}$. BMI is a previously known risk factor for carpal tunnel syndrome both in patients with diabetes [23] 
and in nondiabetic individuals [25]. The mechanism behind the increased risk is not known and is probably multifactorial, possibly including increased intracarpal pressure by excess adipose tissue within the carpal tunnel, which in turn could affect blood flow and risk of nerve ischaemia or might be connected to peripheral neuropathy due to metabolic syndrome [26]. HbAlc was only measured once, which is why the representativeness of a single value for glycemic control can be questioned. All patients had very long diabetes duration and were likely in stable condition. The average HbAlc was $8.1 \%(65 \mathrm{mmol} / \mathrm{mol})$, which is the mean level for all patients with type 1 diabetes in Sweden [27]. There was a highly significant difference in $\mathrm{HbAlc}$, as expected, between the patients with and those without laser-treated retinopathy. This finding indicates that the measured $\mathrm{HbAlc}$ value is robust and strongly suggests, consistent with the findings of other studies $[1,11,13]$, that glycaemic control as estimated by HbA1c plays a role in the connective tissue complications of diabetes.

The associations between impairments of the upper extremity and diabetic microangiopathy and/or neuropathy have previously been reported [1]. In our study, microangiopathy was indirectly assessed by asking the patients about previous laser-treated retinopathy, a measure of severe retinopathy [28]. A significant association between laser-treated retinopathy and risk of having any upper extremity impairments was found in a univariate analysis (data not shown), which is consistent with findings in previous studies [1,2]. However, using a multivariate model including diabetes duration, BMI, $\mathrm{HbAlc}$ and gender, the association between laser-treated retinopathy and any upper extremity impairments was nonsignificant, indicating that the association might be indirect through other variables.

Our subgroup analysis of the separate impairments suggests that there are variations in the risk factor profiles for different impairments, indicating heterogeneous aetiologies. As expected, the prevalence of coeliac disease was higher among patients than controls; however, a new observation is the association between coeliac disease and hand paraesthesia. Both 
carpal tunnel syndrome and coeliac disease are associated with neuropathy [29,30], which could be a conceivable explanation for the association.

Markers of inflammation are cross-sectionally associated with microvascular complications and cardiovascular disease in type 1 diabetes [31]. One earlier study by Bridgman [32] has addressed the likely role of inflammation in diabetes patients with upper extremity impairments. Erythrocyte sedimentation rate was measured in patients with diabetes with and without periarthritis of the shoulder where, however, no significant difference was observed [32]. This result is consistent with our observation that shoulder impairments did not show any association with the inflammatory markers (i.e., high sensitive C-reactive protein, hsCRP). On the contrary, we did find an association of inflammation marker (hsCRP) and finger locking as well as flexed finger, indicating that low-grade inflammation may be associated with upper extremity impairments in type 1 diabetes. Surprisingly, no such association was found in the controls. The data should, however, be interpreted cautiously as only a single hsCRP was used and the impairments are developed for a longer period.

Another unexpected observation was that smoking seems to be a risk factor for upper extremity impairments in controls, but not in patients in our study. Both groups had a similar prevalence of smokers.

\section{Limitations}

Our study is population-based with respect to the fact that all patients with type 1 diabetes in our region fulfilling the eligibility criteria of the study were invited but only $54 \%$ of the women and $38 \%$ of the men accepted to participate. The controls were slightly older and had a higher proportion of females. This is a limitation, but as females seem to have a higher impairment burden, this factor probably blunted the result, making the difference smaller than expected. Another limitation is that the upper extremity impairments were self-reported and 
not based on the clinical examination of the participants. Furthermore, the data on peripheral diabetic neuropathy were not obtained. The questionnaire used contained highly specific questions of what you would look for in a clinical examination when diagnosing upper extremity disorders similar to that used by Larkin et al [1]. The strength of our study is the large number of participants and the matched control group, and to our knowledge, this is the first population-based study of upper extremity impairments in patients with type 1 diabetes.

\section{Conclusion}

Compared to controls without diabetes, patients with type 1 diabetes have a high prevalence of upper extremity impairments, often bilateral, which are strongly associated with activity limitations and are related to glycaemic control. The area is neglected in the clinical setting and is rarely mentioned in national or international guidelines [1]. More knowledge is warranted to improve optimal diagnostic decisions and interventions, including therapeutic strategies as well as possible rehabilitation needs.

\section{Disclosure of interest}

The authors declare that they have no potential conflicts of interest to disclose.

\section{Acknowledgements}

We are grateful to all patients and controls who participated in our study by answering a questionnaire and donating blood samples.

We thank the late Torbjörn Lindström for invaluable advice and support.

\section{Funding}




\begin{abstract}
This work was supported by the Medical Research Council of Southeast Sweden (FORSS), the County council and Stiftelseförvaltningen of Region Östergötland, Sweden.
\end{abstract}

1

2

3

4

5

6

7

8

9

10

11

12

13

14

15

16

17

18

19

20

21

22

23

24

25

26

27

28

29

30

31

32

33

34

35

36

37

38

39

40

41

42

43

44

45

46

47

48

49

50

51

52

53

54

55

56

57

58

59

60

URL: http:/mc.manuscriptcentral.com/dandr Email: davemuller@suffolk.ac.uk 


\section{References}

1. Larkin ME, Barnie A, Braffett BH, Cleary PA, Diminick L, Harth J, Gatcomb P, Golden E, Lipps J, Lorenzi G, et al. Musculoskeletal complications in type 1 diabetes. Diabetes Care. 2014.

2. Cagliero E, Apruzzese W, Perlmutter GS, Nathan DM. Musculoskeletal disorders of the hand and shoulder in patients with diabetes mellitus. Am J Med. 2002;112:487490.

3. Zreik Nasri H. Adhesive capsulitis of the shoulder and diabetes: a meta-analysis of prevalence. Muscles Ligaments Tendons J [Internet]. 2016;5:26-34.

4. Renard E, Jacques D, Chammas M, Poirier JL, Bonifacj C, Jaffiol C, Simon L, All, Allieu Y. Increased prevalence of soft tissue hand lesions in type 1 and type 2 diabetes mellitus: various entities and associated significance. Diabete Metab. 1994;20:513521.

5. Papanas N, Maltezos E. The diabetic hand: a forgotten complication? J Diabetes Complications [Internet]. 2010;24:154-162.

6. Pourmemari MH, Shiri R. Systematic Review or Meta-analysis Diabetes as a risk factor for carpal tunnel syndrome: a systematic review and meta-analysis. Diabet Med. 2016;33:10-16.

7. Moren-Hybbinette I, Moritz U, Schersten B. The Clinical Picture of the Painful Diabetic Shoulder-Natural History, Social Consequences and Analysis of Concomitant Hand Syndrome. Acta Med Scand. 1987;221:73-82.

8. Laslett LL, Burnet SP, Jones JA, Redmond CL, McNeil JD. Musculoskeletal morbidity: The growing burden of shoulder pain and disability and poor quality of life in diabetic outpatients. Clin Exp Rheumatol. 2007;25:422-429.

9. Gamstedt A, Holm-Glad J, Ohlson C., Sundström M. Hand abnormalities are strongly associated with the duration of diabetes mellitus. J Intern Med. 1993;234:189-193.

10. Abate M, Schiavone C, Salini V, Andia I. Management of limited joint mobility in diabetic patients. Diabetes, Metab Syndr Obes Targets Ther. 2013;6:197-207.

11. Ramchurn N, Mashamba C, Leitch E, Arutchelvam V, Narayanan K, Weaver J, Hamilton J, Heycock C, Saravanan V, Kelly C. Upper limb musculoskeletal abnormalities and poor metabolic control in diabetes. Eur J Intern Med [Internet]. 2009;20:718-721.

12. Yian EH, Contreras R, Sodl JF. Effects of Glycemic Control on Prevalence of Diabetic Frozen Shoulder. J Bone Jt Surg Am. 2012;94:919-923.

13. Raje YR, Cracknell G, Davoren PM. Frequency of hand and shoulder symptoms in patients with Type 1 diabetes. Diabet Med. 2015;32:968-971.

14. Nathan DM. The pathophysiology of diabetic complications: How much does the glucose hypothesis explain? In: Annals of Internal Medicine. Vol. 124. ; 1996. pp 8689.

15. Monnier VM, Bautista O, Kenny D, Sell DR, Fogarty J, Dahms W, Cleary PA, Lachin J, Genuth S, Collagen S, et al. as Markers of Diabetic Complications. Diabetes. 1999;48:870-880. 
16. Miller RG, Secrest AM, Sharma RK, Songer TJ, Orchard TJ. Improvements in the life expectancy of type 1 diabetes: The pittsburgh epidemiology of diabetes complications study cohort. Diabetes. 2012;61:2987-2992.

17. Ekdahl C, Eberhardt K, Andersson SI, Svensson B. Assessing disability in patients with rheumatoid arthritis. Use of a Swedish version of the Stanford Health Assessment Questionnaire. Scand J Rheumatol. 1988;17:263-271.

18. Bruce B, Fries JF. The Stanford Health Assessment Questionnaire: dimensions and practical applications. Heal Qual Life Outcomes [Internet]. 2003;1:20.

19. Syngle A, Verma I, Krishan P, Garg N, Syngle V. Minocycline improves peripheral and autonomic neuropathy in type 2 diabetes: MIND study. Neurol Sci. 2014;35:10671073.

20. Levey AS, Stevens LA, Schmid CH, Zhang YL, Castro AF, Feldman HI, Kusek JW, Eggers $\mathrm{P}$, Van Lente F, Greene T, et al. A new equation to estimate glomerular filtration rate. Ann Intern Med. 2009;150:604-12.

21. Arkkila ETP, Kantola IM, Viikari JSA, Ronnemaa T. Shoulder capsulitis in type I and II diabetic patients: association with diabetic complications and related diseases. Ann Rheum Dis. 1996;55:907-914.

22. Luime JJ, Koes BW, Hendriksen IJM, Burdorf A, Verhagen AP, Miedema HS, Verhaar JAN. Prevalence and incidence of shoulder pain in the general population; a systematic review. Scand J Rheumatol [Internet]. 2004;33:73-81.

23. Redmond CL, Bain GI, Laslett LL, McNeil JD. Hand syndromes associated with diabetes: Impairments and obesity predict disability. J Rheumatol. 2009;36:2766-2771.

24. Thyberg I, Hass UAM, Nordenskiöld U, Gerdle B, Skogh T. Activity limitation in rheumatoid arthritis correlates with reduced grip force regardless of sex: The Swedish TIRA project. Arthritis Care Res. 2005;53:886-896.

25. Harris-Adamson C, Eisen EA, Dale AM, Evanoff B, Hegmann KT, Thiese MS, Kapellusch JM, Garg A, Burt S, Bao S, et al. Personal and workplace psychosocial risk factors for carpal tunnel syndrome: a pooled study cohort HHS Public Access. Occup Env Med [Internet]. 2013;70:529-537.

26. Shiri R, Pourmemari MH, Falah-Hassani K, Viikari-Juntura E. The effect of excess body mass on the risk of carpal tunnel syndrome: A meta-analysis of 58 studies. Obes Rev. 2015;16:1094-1104.

27. Steineck I, Cederholm J, Eliasson B, Rawshani A, Eeg-Olofsson K, Svensson A-M, Zethelius B, Avdic T, Landin-Olsson M, Jendle J, et al. Insulin pump therapy, multiple daily injections, and cardiovascular mortality in 18,168 people with type 1 diabetes: observational study. BMJ. 2015;350:h3234.

28. Nordwall M, Abrahamsson M, Dhir M, Fredrikson M, Ludvigsson J, Arnqvist HJ. Impact of HbA 1c, Followed From Onset of Type 1 Diabetes, on the Development of Severe Retinopathy and Nephropathy: The VISS Study (Vascular Diabetic Complications in Southeast Sweden). Diabetes Care [Internet]. 2015;38:308-315.

29. Stamboulis E, Voumvourakis K, Andrikopoulou A, Koutsis G, Tentolouris N, Kodounis A, Tsivgoulis G. Association between asymptomatic median mononeuropathy and diabetic polyneuropathy severity in patients with diabetes mellitus. J Neurol Sci. 2009;278:41-43. 
30. Thawani SP, Brannagan TH, Lebwohl B, Green PHR, Ludvigsson JF. Risk of Neuropathy Among 28232 Patients With Biopsy-Verified Celiac Disease. JAMA Neurol [Internet]. 2015;72:806.

31. Schram MT, Chaturvedi N, Schalkwijk CG, Fuller JH, Stehouwer CDA. Markers of inflammation are cross-sectionally associated with microvascular complications and cardiovascular disease in type 1 diabetes - The EURODIAB Prospective Complications Study. Diabetologia. 2005;48:370-378.

32. Bridgman JF. Periarthritis of the shoulder and diabetes mellitus. Ann Rheum Dis. 1972;31:69-71. 


\section{Legends}

Figure 1. Total prevalence of both bilateral and unilateral upper extremity impairments in patients (black plus striped bar) and controls (grey plus white bar). The proportion of unilateral impairments are shown in striped (patients)/white (controls) and bilateral impairments in black (patients)/grey (controls). The participants are shown if their answers were given with the presence or absence of impairments in both left and right extremities. $* * * \mathrm{p}<0.001$. CT, carpal tunnel; TF, trigger finger.

Figure 2. Distribution of coexisting impairments in patients and controls. The impairments include shoulder stiffness and pain, hand stiffness, hand paraesthesia, finger locking and flexed finger.

Figure 3. HAQ (Health Assessment Questionnaire)-score with presence of impairments or previous surgery, respectively, as well as in subjects reporting no impairment. ${ }^{*} \mathrm{p}<0.05$; ${ }^{* *} \mathrm{p}<0.01 ; * * * \mathrm{p}<0.001$. CT, carpal tunnel; TF, trigger finger.

Figure 4. HAQ (Health Assessment Questionnaire)-score in relation to the number of coexisting impairments in patients with type 1 diabetes. The impairments include shoulder stiffness and pain, hand stiffness, hand paraesthesia, finger locking and flexed finger.

${ }^{*} \mathrm{p}<0.05 ;{ }^{* *} \mathrm{p}<0.01 ;{ }^{* * *} \mathrm{p}<0.001 . \mathrm{CT}$, carpal tunnel; TF, trigger finger. 


\section{Supplementary material}

\section{Principal investigators in the LeDIG study}

County Council of Jönköping:

Johan Blomgren, Department of Internal Medicine, Höglandsjukhuset, Eksjö.

Karen Wahlin, Department of Internal Medicine, Värnamo Hospital,

County Council of Kalmar:

Marianne Fagerberg, Department of Internal Medicine, Kalmar County Hospital, Kalmar

Marika Berg, Department of Internal Medicine, Västervik Hospital, Västervik

County Council of Östergötland:

Christina Hedman, Department of Endocrinology, Linköping University Hospital, Linköping

Ulf Rosenqvist, Department of Internal Medicine, Motala Hospital, Motala

Anna-Maria Ottosson, Department of Internal Medicine, Vrinnevi Hospital, Norrköping 
Table 1. Characteristics of patients and controls

\begin{tabular}{|c|c|c|c|c|c|c|}
\hline & Patients & Controls & \multicolumn{2}{|c|}{ Patients } & \multicolumn{2}{|c|}{ Controls } \\
\hline & All & All & Female & Male & Female & Male \\
\hline Questionnaire & $n=773$ & $n=708$ & $n=421$ & $n=352$ & $n=431$ & $n=277$ \\
\hline Female sex (\%) & 55 & $61^{*}$ & & & & \\
\hline Age (years) & $50 \pm 10$ & $54 \pm 9 *$ & $50 \pm 10^{a}$ & $51.0 \pm 9.6^{b}$ & $53 \pm 10^{a, d}$ & $56 \pm 9^{b, d}$ \\
\hline BMI $\left(\mathrm{kg} / \mathrm{m}^{2}\right)$ & $26.3 \pm 4.1$ & $26.0 \pm 3.9$ & $26.3 \pm 4.3^{\mathrm{a}}$ & $26.1 \pm 3.9$ & $25.6 \pm 4.1^{\mathrm{a}, \mathrm{d}}$ & $26.6 \pm 3.4^{d}$ \\
\hline Diabetes duration (years) & $35 \pm 10$ & & $36 \pm 10^{c}$ & $34 \pm 9^{c}$ & & \\
\hline Current smoker (\%) & 10 & 10.5 & 11 & 8.5 & 11 & 10 \\
\hline Physical demanding & & & & & & \\
\hline occupation (\%) & 31 & 31 & 30 & 31 & 29 & 34 \\
\hline Coeliac disease (\%) & 3 & $1 *$ & $4^{a}$ & 3 & $1^{\mathrm{a}}$ & 1 \\
\hline $\begin{array}{l}\text { Previous cardiovascular event } \\
(\%)^{\dagger}\end{array}$ & 11 & $4 *$ & $7^{a, c}$ & $14^{\mathrm{b}, \mathrm{c}}$ & $3^{a, d}$ & $6^{b, d}$ \\
\hline $\begin{array}{l}\text { Previous myocardial } \\
\text { infarction (\%) }\end{array}$ & 5 & $2^{*}$ & $4^{\mathrm{a}}$ & 7 & $1^{\mathrm{a}, \mathrm{d}}$ & $4^{d}$ \\
\hline Angina pectoris (\%) & 7 & $2^{*}$ & $7^{\mathrm{a}}$ & $7^{b}$ & $1^{\mathrm{a}}$ & $3^{b}$ \\
\hline Previous stroke (\%) & 3 & 2 & 2 & 3 & 1 & 2 \\
\hline Retinopathy $(\%)^{\neq}$ & 39 & & 36 & 42 & & \\
\hline HAQ score & $0.27 \pm 0.02$ & $0.11 \pm 0.01 *$ & $0.35 \pm 0.02^{a, c}$ & $0.18 \pm 0.02^{b, c}$ & $0.13 \pm 0.01^{a, d}$ & $0.08 \pm 0.01^{b, d}$ \\
\hline Blood samples & $n=603$ & $n=531$ & $n=338$ & $n=265$ & $n=331$ & $n=200$ \\
\hline $\mathrm{HbA} 1 \mathrm{c}(\mathrm{mmol} / \mathrm{mol}[\%])$ & $\begin{array}{c}65 \pm 11 \\
{[8.1 \% \pm 1.0]}\end{array}$ & & $\begin{array}{c}64 \pm 10 \\
{[8.0 \% \pm 0.9]}\end{array}$ & $\begin{array}{c}65 \pm 12 \\
{[8.1 \% \pm 1.1]}\end{array}$ & & \\
\hline CRP (mg/L) & $\begin{array}{c}1.0 \\
(0.3-2.7)\end{array}$ & $\begin{array}{c}0.8 \\
(0.3-2.1)^{*}\end{array}$ & $\begin{array}{c}1.1 \\
(0.3-3.2)^{\mathrm{a}}\end{array}$ & $\begin{array}{c}0.8 \\
(0.3-2.3)\end{array}$ & $\begin{array}{c}0.8 \\
(0.3-2.4)^{a}\end{array}$ & $\begin{array}{c}0.8 \\
(0.3-2.0)\end{array}$ \\
\hline
\end{tabular}


The data are presented as the mean \pm SD values or $\%$, except for HAQ score, which is presented as the mean $\pm \mathrm{SE}$ values, and $\mathrm{CRP}$, which is presented as median (range). ${ }^{*} \mathrm{p}<0.05$ when analysed patients with diabetes vs control. Letters ${ }^{\mathrm{a}-\mathrm{d}}$ illustrate significance

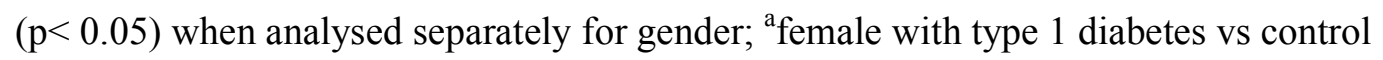
female; ${ }^{b}$ male with type 1 diabetes vs control male; ${ }^{c}$ female with type 1 diabetes vs male with type 1 diabetes; ${ }^{\mathrm{d}}$ control female vs control male.

${ }^{\dagger}$ Previous myocardial infarction, angina and stroke.

${ }^{{ }^{*}}$ Retinopathy defined as self-reported history of laser treatment to either of the eyes. 
Table 2 Multivariate logistic regression in patients with type 1 diabetes

\begin{tabular}{|c|c|c|c|c|c|c|c|c|c|c|}
\hline & \multicolumn{2}{|c|}{ Shoulder impairment } & \multicolumn{2}{|c|}{ Hand stiffness } & \multicolumn{2}{|c|}{ Hand paraesthesia } & \multicolumn{2}{|c|}{ Finger locking } & \multicolumn{2}{|c|}{ Flexed finger } \\
\hline & OR $(95 \% \mathrm{Cl})$ & $\begin{array}{c}p- \\
\text { value }\end{array}$ & OR $(95 \% \mathrm{Cl})$ & $\begin{array}{c}p- \\
\text { value }\end{array}$ & OR $(95 \% \mathrm{Cl})$ & $\begin{array}{c}p- \\
\text { value }\end{array}$ & OR $(95 \% \mathrm{Cl})$ & $\begin{array}{c}p- \\
\text { value }\end{array}$ & OR $(95 \% \mathrm{Cl})$ & $\begin{array}{c}p- \\
\text { value }\end{array}$ \\
\hline \multirow[t]{2}{*}{ Gender } & 1.556 & 0.02 & 1.938 & 0.01 & 1.721 & 0.01 & 1.489 & 0.05 & 1.291 & n.s. \\
\hline & $(1.066-2.272)$ & & $(1.31-2.867)$ & & $(1.195-2.48)$ & & $(0.998-2.221)$ & & $(0.851-1.959)$ & \\
\hline \multirow[t]{2}{*}{ Age } & 1.008 & n.s. & 1.031 & 0.02 & 1.006 & n.s. & 1.021 & n.s. & 1.028 & $(0.06)$ \\
\hline & $(0.983-1.034)$ & & $(1.004-1.058)$ & & $(0.981-1.031)$ & & $(0.994-1.049)$ & & $(0.999-1.058)$ & \\
\hline \multirow[t]{2}{*}{ Duration } & 1.03 & 0.01 & 1.016 & n.s. & 0.995 & n.s. & 1.006 & n.s. & 1.039 & 0.01 \\
\hline & $(1.006-1.055)$ & & $(0.992-1.041)$ & & $(0.972-1.018)$ & & $(0.981-1.03)$ & & $(1.013-1.066)$ & \\
\hline \multirow[t]{2}{*}{ BMI } & 1.058 & 0.02 & 0.98 & n.s. & 1.07 & 0.01 & 0.974 & n.s. & 0.958 & N.s. \\
\hline & $(1.009-1.11)$ & & $(0.934-1.028)$ & & $(1.021-1.122)$ & & $(0.927-1.024)$ & & $(0.909-1.009)$ & \\
\hline \multirow[t]{2}{*}{ Smoking } & 1.602 & $(0.08)$ & 1.277 & n.s. & 1.336 & n.s. & 1.264 & n.s. & 1.256 & N.s. \\
\hline & $(0.953-2.692)$ & & $(0.757-2.154)$ & & $(0.806-2.214)$ & & $(0.746-2.143)$ & & $(0.72-2.193)$ & \\
\hline \multirow[t]{2}{*}{ Celiac disease } & 2.179 & n.s. & 3.156 & 0.03 & 5.492 & 0.01 & 1.74 & n.s. & 1.329 & N.s. \\
\hline & $(0.77-6.165)$ & & $(1.104-9.024)$ & & $(1.537-19.616)$ & & $(0.635-4.769$ & & $(0.471-3.754)$ & \\
\hline \multirow[t]{2}{*}{ Retinopathy } & 1.36 & n.s. & 0.958 & n.s. & 0.947 & n.s. & 1.085 & n.s. & 1.502 & $(0.06)$ \\
\hline & $(0.916-2.018)$ & & $(0.638-1.437)$ & & $(0.641-1.4)$ & & $(0.716-1.643)$ & & $(0.984-2.293)$ & \\
\hline \multirow[t]{2}{*}{ CVD } & 0.91 & n.s. & 1.537 & n.s. & 1.397 & n.s. & 1.731 & $(0.07)$ & 1.794 & $(0.06)$ \\
\hline & $(0.502-1.651)$ & & $(0.847-2.787)$ & & $(0.772-2.528)$ & & $(0.967-3.101)$ & & $(0.983-3.273)$ & \\
\hline \multirow[t]{2}{*}{ HbA1c } & 1.017 & 0.05 & 1.012 & n.s. & 1.014 & n.s. & 1.012 & n.s. & 1.007 & n.s. \\
\hline & $(1-1.034)$ & & $0.995-1.03)$ & & $(0.997-1.031)$ & & $(0.995-1.03)$ & & $(0.989-1.026)$ & \\
\hline \multirow[t]{2}{*}{ GFR } & 1.009 & n.s. & 1.009 & n.s. & 1.002 & n.s. & 0.999 & n.s. & 1.009 & n.s. \\
\hline & $(0.998-1.02)$ & & $(0.998-1.02)$ & & $(0.991-1.012)$ & & $(0.988-1.01)$ & & $(0.998-1.022)$ & \\
\hline \multirow[t]{2}{*}{ hsCRP } & 0.919 & n.s. & 1.1 & n.s. & 0.934 & n.s. & 1.18 & 0.05 & 1.241 & 0.01 \\
\hline & $(0.784-1.077)$ & & $(0.938-1.289)$ & & $(0.8-1.09)$ & & $(1.003-1.387)$ & & $(1.048-1.469)$ & \\
\hline
\end{tabular}

OR $=$ odds ratio.

$C V D=$ cardiovascular disease

GFR = glomerular filtration rate

hsCRP = high sensitivity C-reactive protein 
Figure 1. Total prevalence of both bilateral and unilateral upper extremity impairments in patients (black plus striped bar) and controls (grey plus white bar). The proportion of unilateral impairments are shown in striped (patients)/white (controls) and bilateral impairments in black (patients)/grey (controls). The participants are shown if their answers were given with the presence or absence of impairments in both left and right extremities. $* * * p<0.001$. CT, carpal tunnel; TF, trigger finger.

$99 \times 50 \mathrm{~mm}(300 \times 300 \mathrm{DPI})$ 


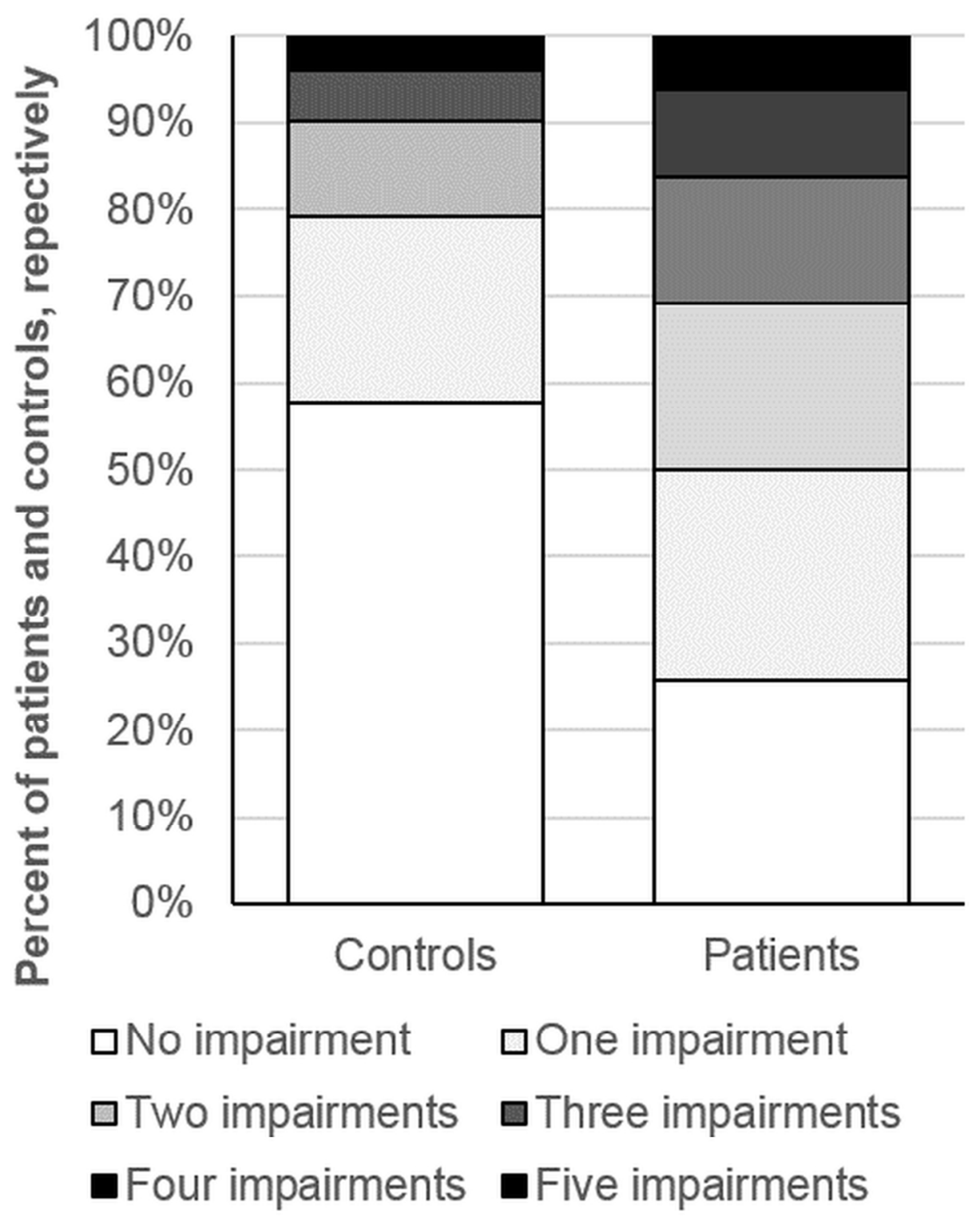

Figure 2. Distribution of coexisting impairments in patients and controls. The impairments include shoulder stiffness and pain, hand stiffness, hand paraesthesia, finger locking and flexed finger.

$110 \times 133 \mathrm{~mm}(300 \times 300$ DPI) 
Figure 3. HAQ (Health Assessment Questionnaire)-score with presence of impairments or previous surgery, respectively, as well as in subjects reporting no impairment. $*_{p}<0.05 ; * * p<0.01 ; * * * p<0.001$. CT, carpal tunnel; TF, trigger finger.

$127 \times 81 \mathrm{~mm}(300 \times 300$ DPI $)$ 
Figure 4. HAQ (Health Assessment Questionnaire)-score in relation to the number of coexisting impairments in patients with type 1 diabetes. The impairments include shoulder stiffness and pain, hand stiffness, hand paraesthesia, finger locking and flexed finger. ${ }^{*} \mathrm{p}<0.05 ; * * \mathrm{p}<0.01 ; * * * \mathrm{p}<0.001$. CT, carpal tunnel; TF, trigger finger.

\section{$72 \times 48 m m(300 \times 300$ DPI $)$}


Supplementary table s1 Multivariate logistic regression in controls

\begin{tabular}{|c|c|c|c|c|c|c|c|c|c|c|c|c|}
\hline & \multirow{2}{*}{\multicolumn{2}{|c|}{ Any symptom }} & \multirow{2}{*}{\multicolumn{2}{|c|}{ Shoulder impairment }} & \multirow{2}{*}{\multicolumn{2}{|c|}{ Hand stiffness }} & \multirow{2}{*}{\multicolumn{2}{|c|}{ Hand paraesthesia }} & \multirow{2}{*}{\multicolumn{2}{|c|}{ Finger locking }} & & \\
\hline & & & & & & & & & & & \multicolumn{2}{|c|}{ Flexed finger } \\
\hline & OR $(95 \% \mathrm{Cl})$ & $p$-value & OR (95\%Cl) & $\begin{array}{l}p- \\
\text { value }\end{array}$ & OR $(95 \% \mathrm{Cl})$ & $p$-value & OR (95\%Cl) & $\begin{array}{l}p- \\
\text { value }\end{array}$ & OR $(95 \% \mathrm{Cl})$ & $\begin{array}{l}p- \\
\text { value } \\
\end{array}$ & OR $(95 \% \mathrm{Cl})$ & $\begin{array}{l}p- \\
\text { value } \\
\end{array}$ \\
\hline \multirow{2}{*}{ Gender } & 2.061 & 0.01 & 1.905 & 0.02 & 2.384 & 0.01 & 1.909 & 0.01 & 1.305 & n.s. & 0.839 & n.s. \\
\hline & $(1.389-3.058)$ & & $(1.11-3.269)$ & & $(1.343-4.232)$ & & $(1.226-2.971)$ & & $(0.729-2.337)$ & & $(0.398-1.768)$ & \\
\hline \multirow{2}{*}{ Age } & 1.036 & 0.01 & 1.03 & $(0.08)$ & 1.048 & 0.01 & 1.009 & n.s. & 1.048 & 0.02 & 1.064 & 0.02 \\
\hline & $(1.012-1.061)$ & & $(0.997-1.063)$ & & $(1.013-1.085)$ & & $(0.983-1.035)$ & & $(1.008-1.09)$ & & $(1.01-1.12)$ & \\
\hline \multirow{2}{*}{ BMI } & 1.047 & $(0.09)$ & 1.069 & 0.05 & 1.03 & n.s. & 1.077 & 0.01 & 1.009 & n.s. & 0.943 & n.s. \\
\hline & $(0.993-1.105)$ & & $(1.001-1.141)$ & & $(0.962-1.102)$ & & $(1.017-1.14)$ & & $(0.935-1.088)$ & & $(0.846-1.051)$ & \\
\hline \multirow{2}{*}{ Smoking } & 1.955 & 0.02 & 2.973 & 0.01 & 2.522 & 0.01 & 1.502 & n.s. & 1.945 & $(0.07)$ & 4.331 & 0.01 \\
\hline & $(1.128-3.388)$ & & $(1.617-5.464)$ & & $(1.351-4.708)$ & 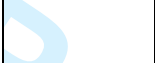 & $(0.843-2.674)$ & & $(0.952-3.972)$ & & $(1.983-9.458)$ & \\
\hline \multirow{2}{*}{$\begin{array}{c}\text { Celiac } \\
\text { disease }\end{array}$} & 0.268 & n.s. & 1.014 & n.s. & 0 & n.s. & 0 & n.s. & 0 & n.s. & 0 & n.s. \\
\hline & $(0.027-2.674)$ & & $(0,1-10.243)$ & & $(1.104-9.024)$ & & 0 & & 0 & & 0 & \\
\hline \multirow{2}{*}{ CVD } & 1,401 & n.s. & 0.9 & n.s. & 2.193 & n.s. & 1.594 & n.s. & 2.703 & 0.04 & 1.549 & n.s. \\
\hline & $(0.593-3.311)$ & & $(0.285-2.84)$ & & $(0.847-2.787)$ & & $(0.651-3.903)$ & & $(1.026-7.122)$ & & $(0.4-6.002)$ & \\
\hline \multirow{2}{*}{ GFR } & 1.021 & 0.01 & 1.018 & n.s. & $\begin{array}{c}1.034 \\
(1.01-1.059) \\
\end{array}$ & 0.01 & 1.012 & n.s. & 1.004 & n.s. & 1.029 & n.s. \\
\hline & $(1 . .005-1.038)$ & & $(0.996-1.041)$ & & & & $(0.995-1.03)$ & & $(0.98-1.028)$ & & $(0.994-1.064)$ & \\
\hline \multirow{2}{*}{ hsCRP } & 1.113 & n.s. & 1.072 & n.s. & 1.091 & n.s. & 1.166 & n.s. & 1.035 & n.s. & 1.007 & n.s. \\
\hline & $(0.926-1.339)$ & & $(0.842-1.365)$ & & $(0.938-1.289)$ & & $(0.955-1.424)$ & & $(0.791-1.354)$ & & $(0.71-1.428)$ & \\
\hline
\end{tabular}

OR = odds ratio.

$\mathrm{CVD}=$ cardiovascular disease

GFR = glomerular filtration rate URL: http:/mc.manuscriptcentral.com/dandr Email: davemuller@suffolk.ac.uk hsCRP = high sensn.s. itivity C-reactive protein 


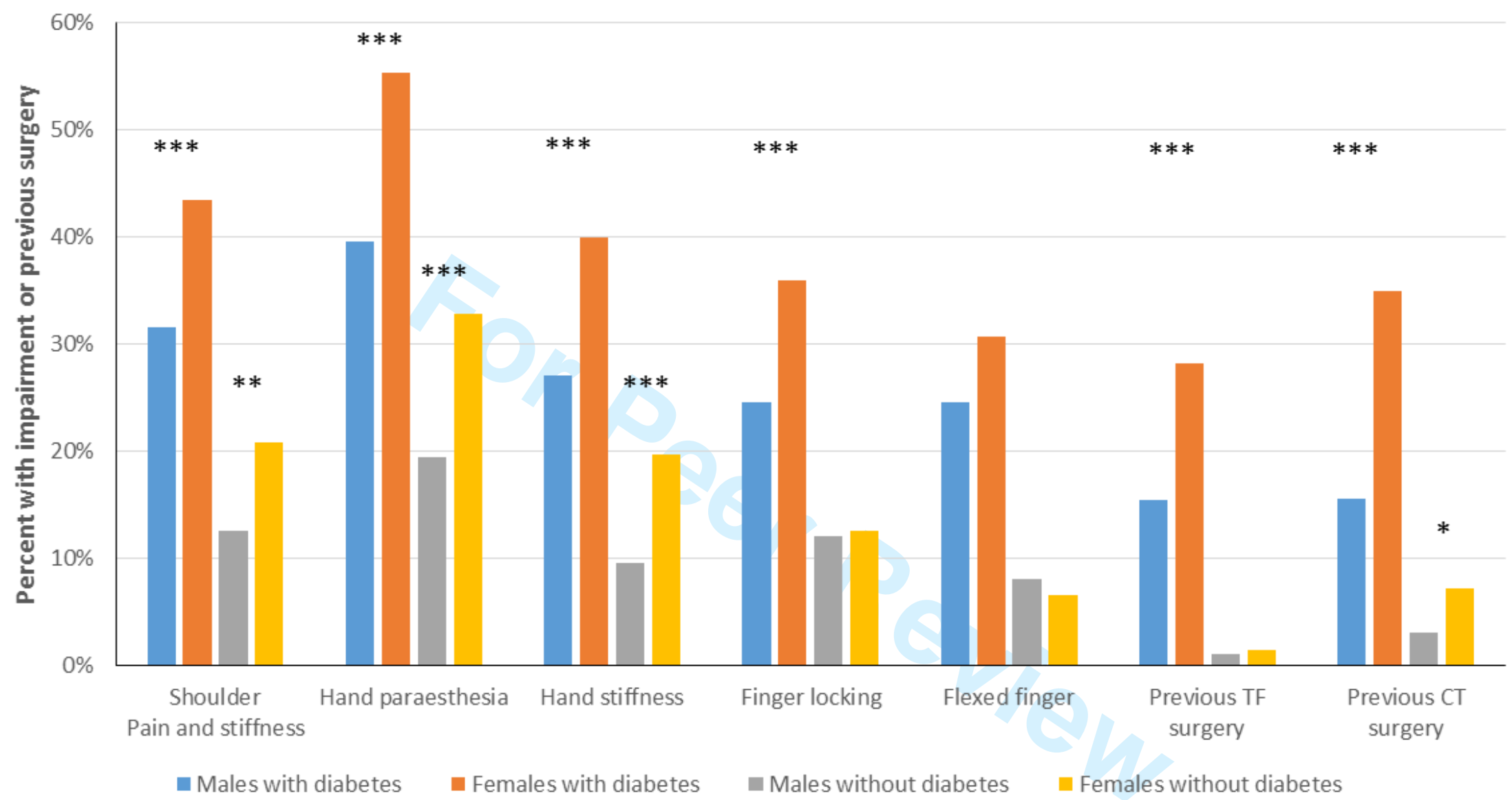

Figure s1. Gender differences regarding the prevalence of upper extremity impairments in patients and controls. An analysis was performed to compare female vs male in diabetes and controls, respectively. ${ }^{*} p<0.05 ;{ }^{*} p<0.01 ;{ }^{* *} p<0.001$. CT, carpal tunnel; TF, trigger finger. 


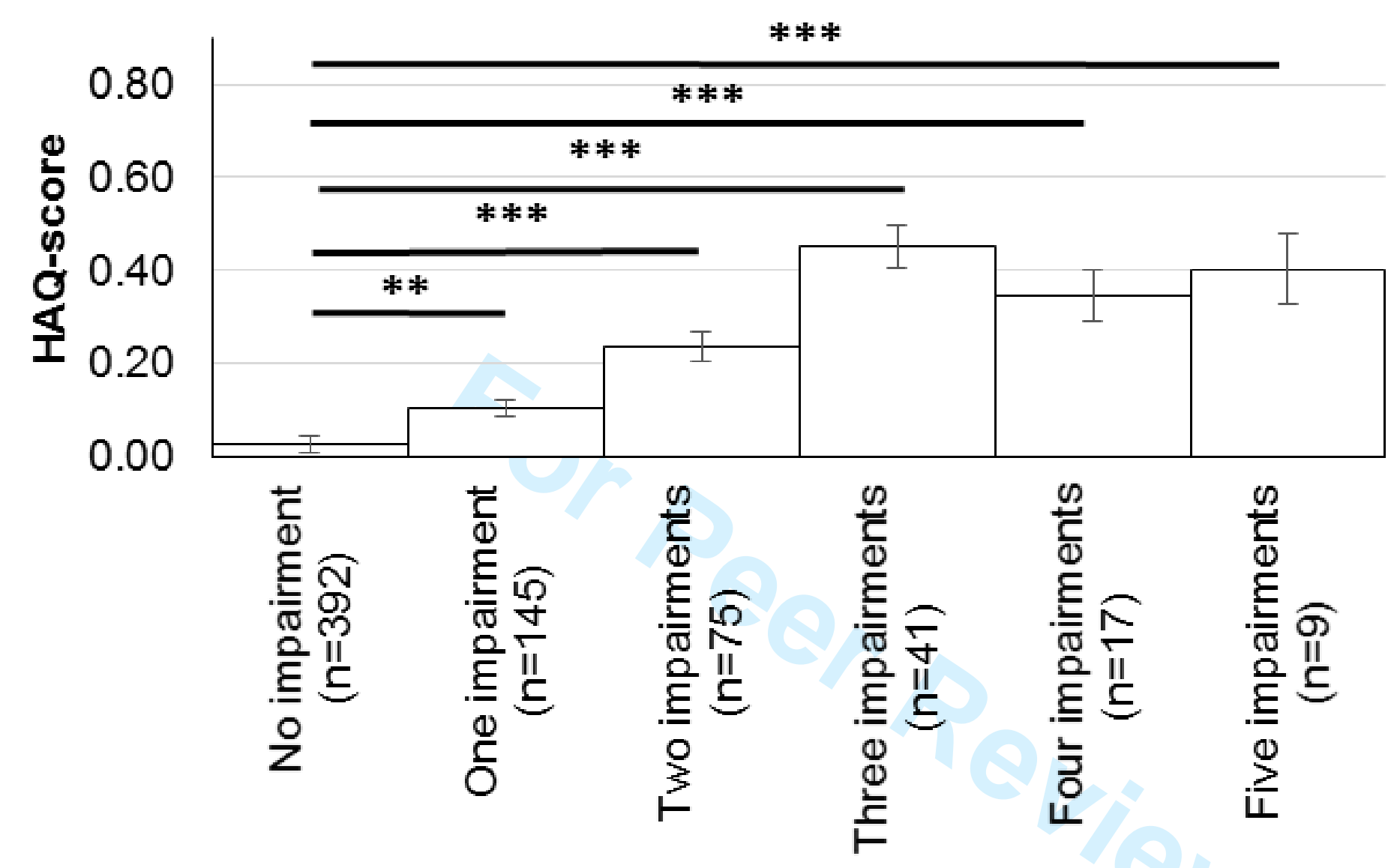

Figure s2. HAQ (Health Assessment Questionnaire)-score in relation to the number of coexisting impairments in controls. The impairments include shoulder stiffness and pain, hand stiffness, hand paraesthesia, finger locking and flexed finger. ${ }^{*} p<0.05 ;{ }^{* *} p<0.01 ;{ }^{* * *} p<0.001 . \mathrm{CT}$, carpal tunnel; TF, trigger finger. 


\section{Questionnaire}

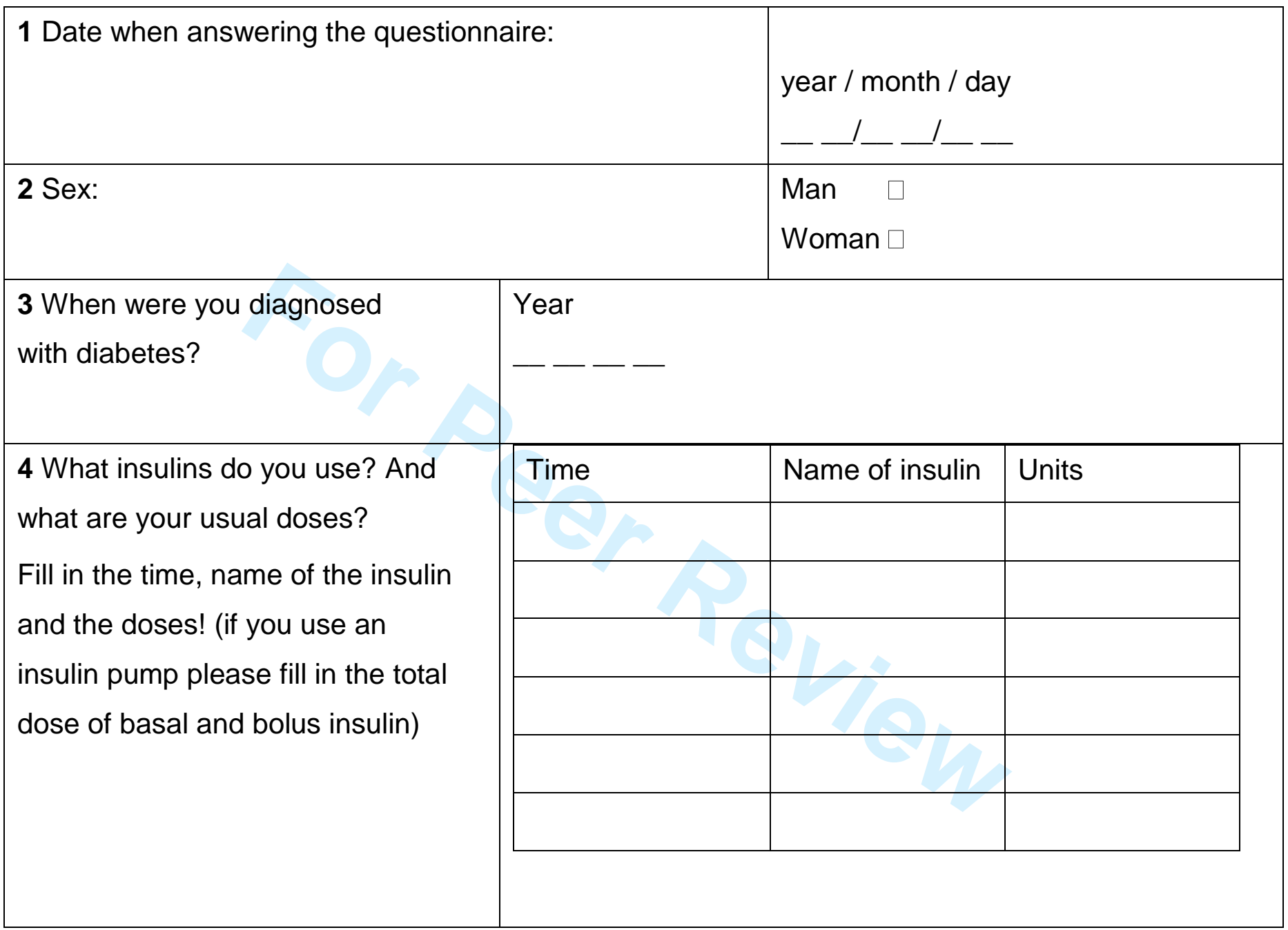




\section{page 2}

\begin{tabular}{|c|c|c|}
\hline \multicolumn{3}{|c|}{$\begin{array}{l}\text { In the following set of questions (5-16) which regard joints and muscles please answer } \\
\text { separately right and left "shoulder/arm/hand" or "fingers/hand" respectively. The questions } \\
\text { regard the past few years. }\end{array}$} \\
\hline & Right & Left \\
\hline 5 Do you have pain/ache in shoulder joints? & Yes $\square \quad$ No $\square$ & Yes $\square \quad$ No $\square$ \\
\hline 6 Do you have stiffness in shoulder joints? & Yes $\square \quad$ No $\square$ & Yes $\square \quad$ No $\square$ \\
\hline 7 Do you have pain/ache in the hand or forearm? & Yes $\square \quad$ No $\square$ & Yes $\square \quad$ No $\square$ \\
\hline 8 Are you stiff in hand or forearm? & Yes $\square \quad$ No $\square$ & Yes $\square \quad$ No $\square$ \\
\hline $\begin{array}{l}9 \text { Do you have tingling or loss of sensation/ } \\
\text { numbness in fingers? }\end{array}$ & Yes $\square \quad$ No $\square$ & Yes $\square \quad$ No $\square$ \\
\hline $\begin{array}{l}10 \text { Do you wake at night due to pain or } \\
\text { tingling/loss of sensation in hands? }\end{array}$ & Yes $\square \quad$ No $\square$ & Yes $\square$ No $\square$ \\
\hline 11 Do you experience weakness in the hand? & Yes $\square \quad$ No $\square$ & Yes $\square$ No $\square$ \\
\hline $\begin{array}{l}12 \text { Have you ever had surgery for carpal tunnel } \\
\text { syndrome (nerve entrapment in wrist)? }\end{array}$ & Yes $\square \quad$ No $\square$ & Yes $\square \quad$ No $\square$ \\
\hline $\begin{array}{l}13 \text { Does it ever happen that one of the fingers } \\
\text { "lock" when trying to bend it? In which hand? }\end{array}$ & Yes $\square \quad$ No $\square$ & $\square \quad$ No $\square$ \\
\hline 14 Do you have "tendon nodules" in the palm? & Yes $\square \quad$ No $\square$ & Yes $\square \quad$ No $\square$ \\
\hline
\end{tabular}

URL: http:/mc.manuscriptcentral.com/dandr Email: davemuller@suffolk.ac.uk 


\begin{tabular}{|c|c|c|}
\hline $\begin{array}{l}15 \text { Have you ever had surgery for "tendon } \\
\text { nodules" or a stricture in the tendon sheath of the } \\
\text { palm? }\end{array}$ & Yes $\square \quad$ No $\square$ & Yes $\square \quad$ No $\square$ \\
\hline $\begin{array}{l}16 \text { Have you trouble straightening any } \\
\text { finger/fingers? On which hand? }\end{array}$ & Yes $\square \quad$ No $\square$ & Yes $\square \quad$ No $\square$ \\
\hline 17 Which hand do you write with? & Right $\square$ & Left $\square$ \\
\hline \multicolumn{3}{|c|}{$\begin{array}{l}18 \text { If you have joint- or muscle problems somewhere else than shoulder, arm, hand or } \\
\text { fingers, describe them briefly (location, type of problem and duration. For example:stiffness in } \\
\text { both knees for about } 2 \text { years). }\end{array}$} \\
\hline
\end{tabular}


page 3

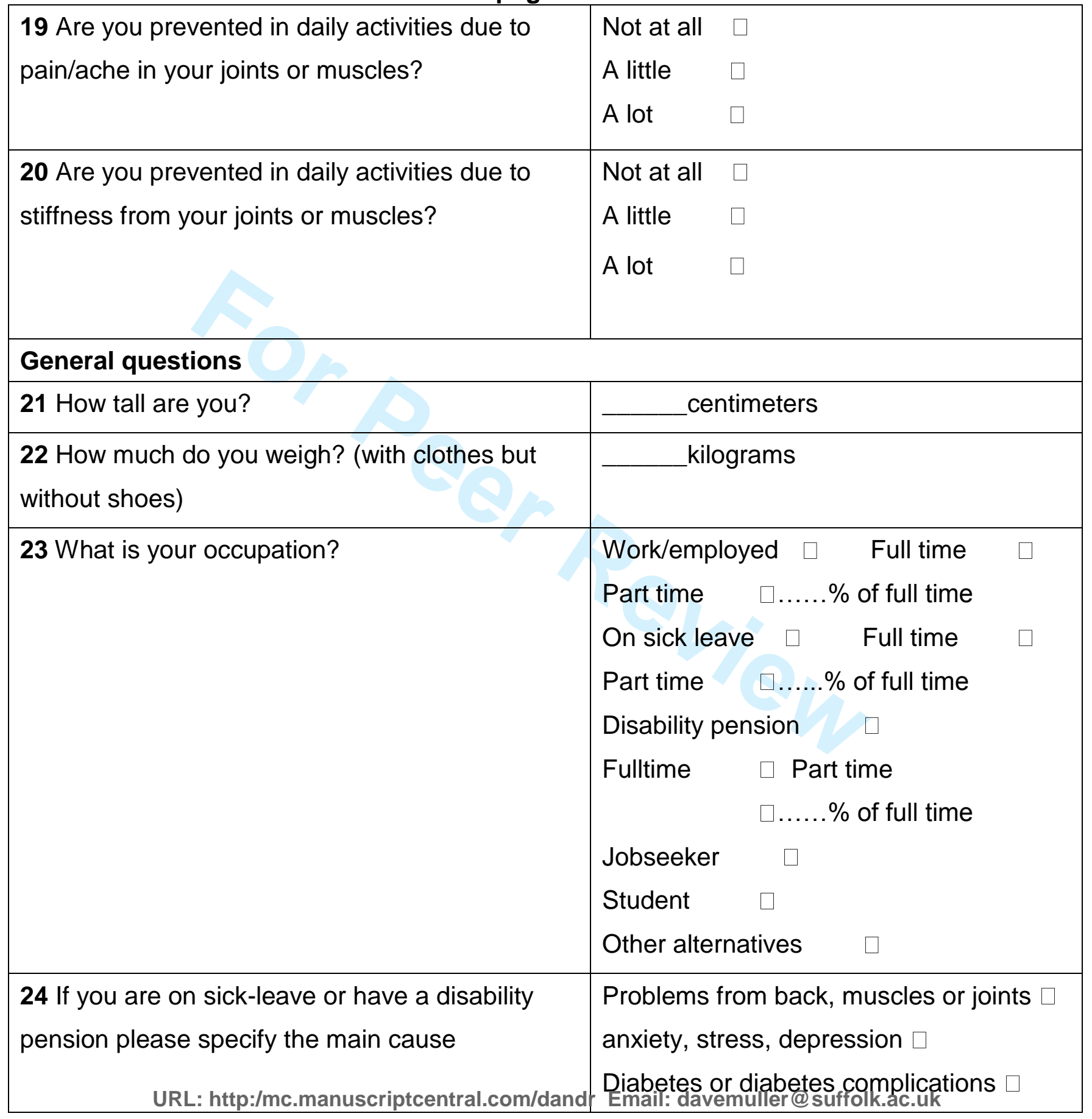




\begin{tabular}{|l|l|}
\hline & $\begin{array}{l}\text { specify } \\
\text { what:.............................................. } \\
\text { Other alternatives }\end{array}$ \\
\hline $\begin{array}{l}\text { Answer this question if you are currently } \\
\text { employed! } \\
\mathbf{2 5} \text { Is your work physically demanding? }\end{array}$ & $\begin{array}{l}\text { No, mostly sedentary } \\
\text { Mobile but not physically demanding } \\
\text { Physically demanding }\end{array}$ \\
\hline $\begin{array}{l}\text { Answer this question if you are currently } \\
\text { employed or if you have been employed! } \\
\mathbf{2 6} \text { Through your total occupational life would you } \\
\text { say your work has been physically demanding? }\end{array}$ & $\begin{array}{l}\text { Nobile but not physically demanding } \\
\text { Physically demanding } \square\end{array}$ \\
\hline
\end{tabular}


page 4

\begin{tabular}{|c|c|}
\hline 27 Do you drink coffee? & $\begin{array}{l}\text { Never or almost never } \square \\
1-2 \text { cups/week } \square \\
1-2 \text { cups/day } \square \\
>2 \text { cups/day } \square\end{array}$ \\
\hline 28 Do you drink alcohol? & $\begin{array}{l}\text { Never or almost never } \square \\
1-2 \text { times per week } \square \\
>2 \text { times per week but not daily } \square \text { Daily } \square\end{array}$ \\
\hline $\begin{array}{l}29 \text { One standard glass of alcohol corresponds to } \\
50 \mathrm{cl} \text { medium-strong beer, } 33 \mathrm{cl} \text { strong beer, } 15 \\
\mathrm{cl} \text { wine or } 4 \mathrm{cl} \text { liquor. Roughly how many } \\
\text { standard glasses do you drink per week? }\end{array}$ & $\begin{array}{l}\text { None } \square \\
\text { Number }\end{array}$ \\
\hline 30 Do you smoke? & $\begin{array}{l}\text { Yes } \\
\text { number of cigarettes /day: } \\
\text { Yes but not daily/ "party smoker" } \\
\text { No, stopped smoking (year): } \\
\text { No, never smoked }\end{array}$ \\
\hline 31 Do you snuff? & $\begin{array}{l}\text { Yes } \\
\text { number of snuff boxes /week: } \\
\text { Yes but not daily } \square \\
\text { No stopped snuffing (year): } \\
\text { No, never snuffed } \square\end{array}$ \\
\hline $\begin{array}{l}32 \text { Physical activity ( } 30 \text { minutes walking or } \\
\text { equivalent, individually adjusted and all forms of } \\
\text { activities count): http:/mc.manuscriptcentral.com/dan }\end{array}$ & $\begin{array}{l}\text { Never } \square \\
<1 \text { time/week } \square \\
\text { Regularly 1-2 times per week } \\
\text { Emmall: davemuller@suffolk.ac.uk }\end{array}$ \\
\hline
\end{tabular}




\begin{tabular}{|c|c|}
\hline & $\begin{array}{l}\text { Regularly 3-5 times per week } \\
\text { Daily }\end{array}$ \\
\hline \multicolumn{2}{|c|}{ Questions on other diseases and medication } \\
\hline $\begin{array}{l}33 \text { Do you have celiac disease (gluten } \\
\text { intolerance)? }\end{array}$ & Yes $\quad \square \quad$ No $\square$ \\
\hline 34 Have you ever sustained a fracture? & 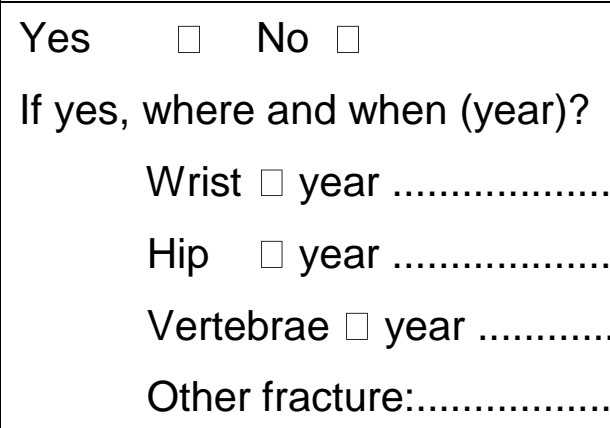 \\
\hline
\end{tabular}




\begin{tabular}{|c|c|c|c|c|}
\hline \multicolumn{5}{|l|}{ page 5} \\
\hline $\begin{array}{l}35 \text { Do you have or have you had angina } \\
\text { pectoris? }\end{array}$ & Yes & $\square$ & No & $\square$ \\
\hline 36 Have you had a heart attack? & Yes & $\square$ & No & $\square$ \\
\hline 37 Have you had a stroke? & Yes & $\square$ & No & $\square$ \\
\hline $\begin{array}{l}38 \text { Have you received laser treatment to any of } \\
\text { your eyes? }\end{array}$ & Yes & $\square$ & No & $\square$ \\
\hline 39 Are you medicating with cortisone pills? & Yes & $\square$ & No & $\square$ \\
\hline $\begin{array}{l}40 \text { Are you on medication against high blood } \\
\text { pressure? }\end{array}$ & Yes & $\square$ & No & $\square$ \\
\hline 41 Are you on lipid lowering medication? & Yes & $\square$ & No & $\square$ \\
\hline $\begin{array}{l}\text { Answer if you are a woman: } \\
42 \text { Do you use birth control pills or hormone pills } \\
\text { due to menopause symptoms? }\end{array}$ & Yes & $\square$ & No & $\square$ \\
\hline $\begin{array}{l}\text { Answer if you are a woman: } \\
43 \text { Are you pregnant? }\end{array}$ & Yes & $\square$ & No & $\square$ \\
\hline
\end{tabular}


Supplementary table s1 Multivariate logistic regression in controls

\begin{tabular}{|c|c|c|c|c|c|c|c|c|c|c|c|c|}
\hline & \multicolumn{2}{|c|}{ Any symptom } & \multicolumn{2}{|c|}{ Shoulder impairment } & \multicolumn{2}{|c|}{ Hand stiffness } & \multicolumn{2}{|c|}{ Hand paraesthesia } & \multicolumn{2}{|c|}{ Finger locking } & \multicolumn{2}{|c|}{ Flexed finger } \\
\hline & OR (95\%Cl) & $p$-value & OR $(95 \% \mathrm{Cl})$ & $\begin{array}{l}p- \\
\text { value }\end{array}$ & OR $(95 \% \mathrm{Cl})$ & $p$-value & OR $(95 \% \mathrm{Cl})$ & $\begin{array}{l}p- \\
\text { value }\end{array}$ & OR $(95 \% \mathrm{Cl})$ & $\begin{array}{l}p- \\
\text { value }\end{array}$ & OR $(95 \% \mathrm{Cl})$ & $\begin{array}{l}p- \\
\text { value }\end{array}$ \\
\hline \multirow{2}{*}{ Gender } & 2.061 & 0.01 & 1.905 & 0.02 & 2.384 & 0.01 & 1.909 & 0.01 & 1.305 & n.s. & 0.839 & n.s. \\
\hline & $(1.389-3.058)$ & & $(1.11-3.269)$ & & $(1.343-4.232)$ & & $(1.226-2.971)$ & & $(0.729-2.337)$ & & $(0.398-1.768)$ & \\
\hline \multirow{2}{*}{ Age } & 1.036 & 0.01 & 1.03 & (0.08) & 1.048 & 0.01 & 1.009 & n.s. & 1.048 & 0.02 & 1.064 & 0.02 \\
\hline & $(1.012-1.061)$ & & $(0.997-1.063)$ & & $(1.013-1.085)$ & & $(0.983-1.035)$ & & $(1.008-1.09)$ & & $(1.01-1.12)$ & \\
\hline \multirow{2}{*}{ BMI } & 1.047 & $(0.09)$ & 1.069 & 0.05 & 1.03 & n.s. & 1.077 & 0.01 & 1.009 & n.s. & 0.943 & n.s. \\
\hline & $(0.993-1.105)$ & & $(1.001-1.141)$ & & $(0.962-1.102)$ & & $(1.017-1.14)$ & & $(0.935-1.088)$ & & $(0.846-1.051)$ & \\
\hline \multirow{2}{*}{ Smoking } & 1.955 & 0.02 & 2.973 & 0.01 & 2.522 & 0.01 & 1.502 & n.s. & 1.945 & $(0.07)$ & 4.331 & 0.01 \\
\hline & $(1.128-3.388)$ & & $(1.617-5.464)$ & & $(1.351-4.708)$ & & $(0.843-2.674)$ & & $(0.952-3.972)$ & & $(1.983-9.458)$ & \\
\hline \multirow{2}{*}{$\begin{array}{c}\text { Celiac } \\
\text { disease }\end{array}$} & 0.268 & n.s. & 1.014 & n.s. & 0 & n.s. & 0 & n.s. & 0 & n.s. & 0 & n.s. \\
\hline & $(0.027-2.674)$ & & $(0,1-10.243)$ & & $(1.104-9.024)$ & & 0 & & 0 & & 0 & \\
\hline \multirow{2}{*}{ CVD } & 1,401 & n.s. & 0.9 & n.s. & 2.193 & n.s. & 1.594 & n.s. & 2.703 & 0.04 & 1.549 & n.s. \\
\hline & $(0.593-3.311)$ & & $(0.285-2.84)$ & & $(0.847-2.787)$ & & $(0.651-3.903)$ & & $(1.026-7.122)$ & & $(0.4-6.002)$ & \\
\hline \multirow{2}{*}{ GFR } & 1.021 & 0.01 & 1.018 & n.s. & $\begin{array}{c}1.034 \\
(1.01-1.059)\end{array}$ & 0.01 & 1.012 & n.s. & 1.004 & n.s. & 1.029 & n.s. \\
\hline & $(1 . .005-1.038)$ & & $(0.996-1.041)$ & & & & $(0.995-1.03)$ & & $(0.98-1.028)$ & & $(0.994-1.064)$ & \\
\hline \multirow{2}{*}{ hsCRP } & 1.113 & n.s. & 1.072 & n.s. & 1.091 & n.s. & 1.166 & n.s. & 1.035 & n.s. & 1.007 & n.s. \\
\hline & $(0.926-1.339)$ & & $(0.842-1.365)$ & & $(0.938-1.289)$ & & $(0.955-1.424)$ & & $(0.791-1.354)$ & & $(0.71-1.428)$ & \\
\hline
\end{tabular}

$\mathrm{OR}=$ odds ratio.

$\mathrm{CVD}=$ cardiovascular disease

GFR = glomerular filtration rate

hsCRP = high sensn.s. itivity C-reactive protein 


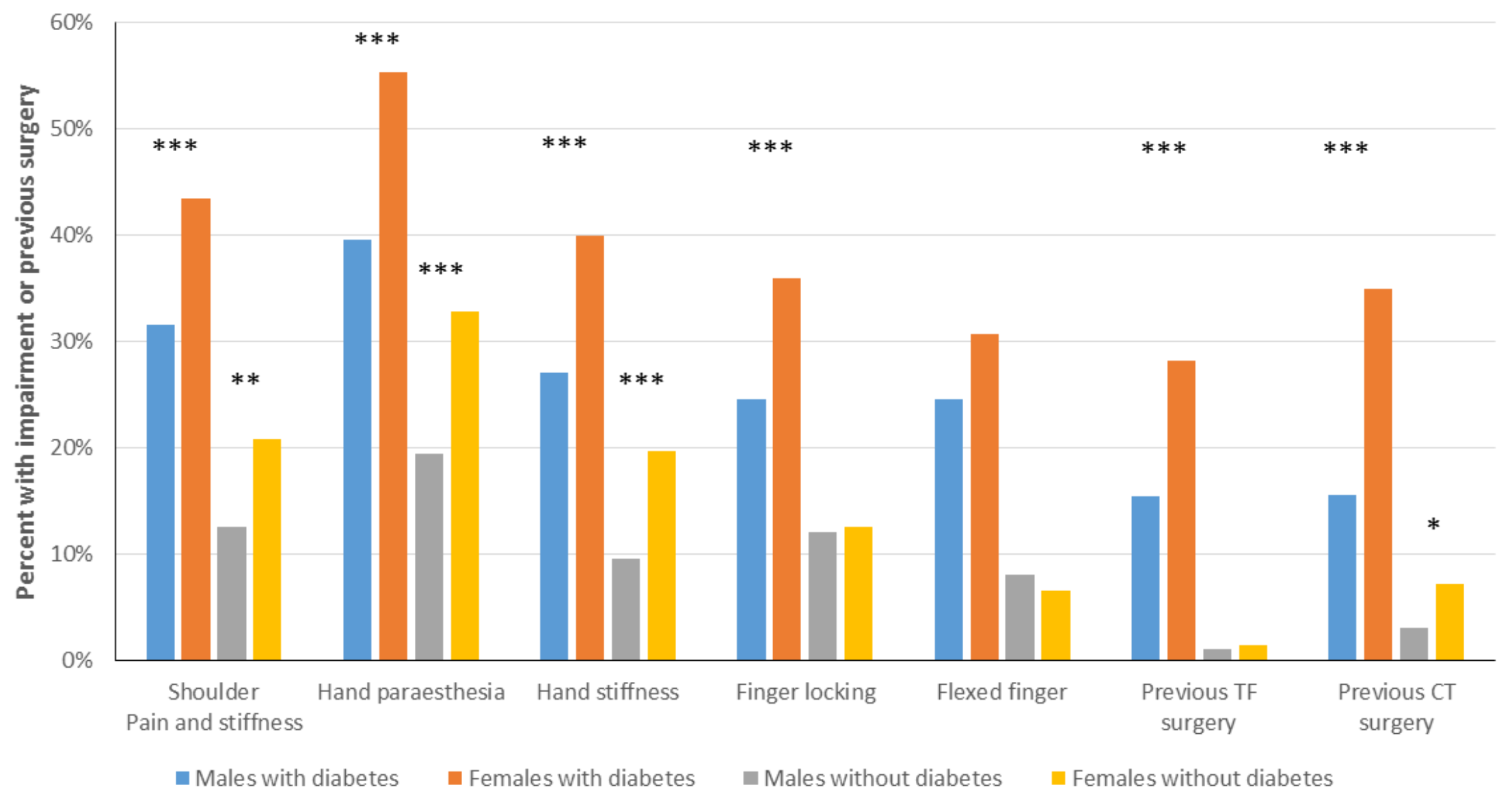

Figure s1. Gender differences regarding the prevalence of upper extremity impairments in patients and controls. An analysis was performed to compare female vs male in diabetes and controls, respectively. ${ }^{*} p<0.05 ;{ }^{* *} p<0.01 ;{ }^{* *} p<0.001 . \mathrm{CT}$, carpal tunnel; TF, trigger finger. 


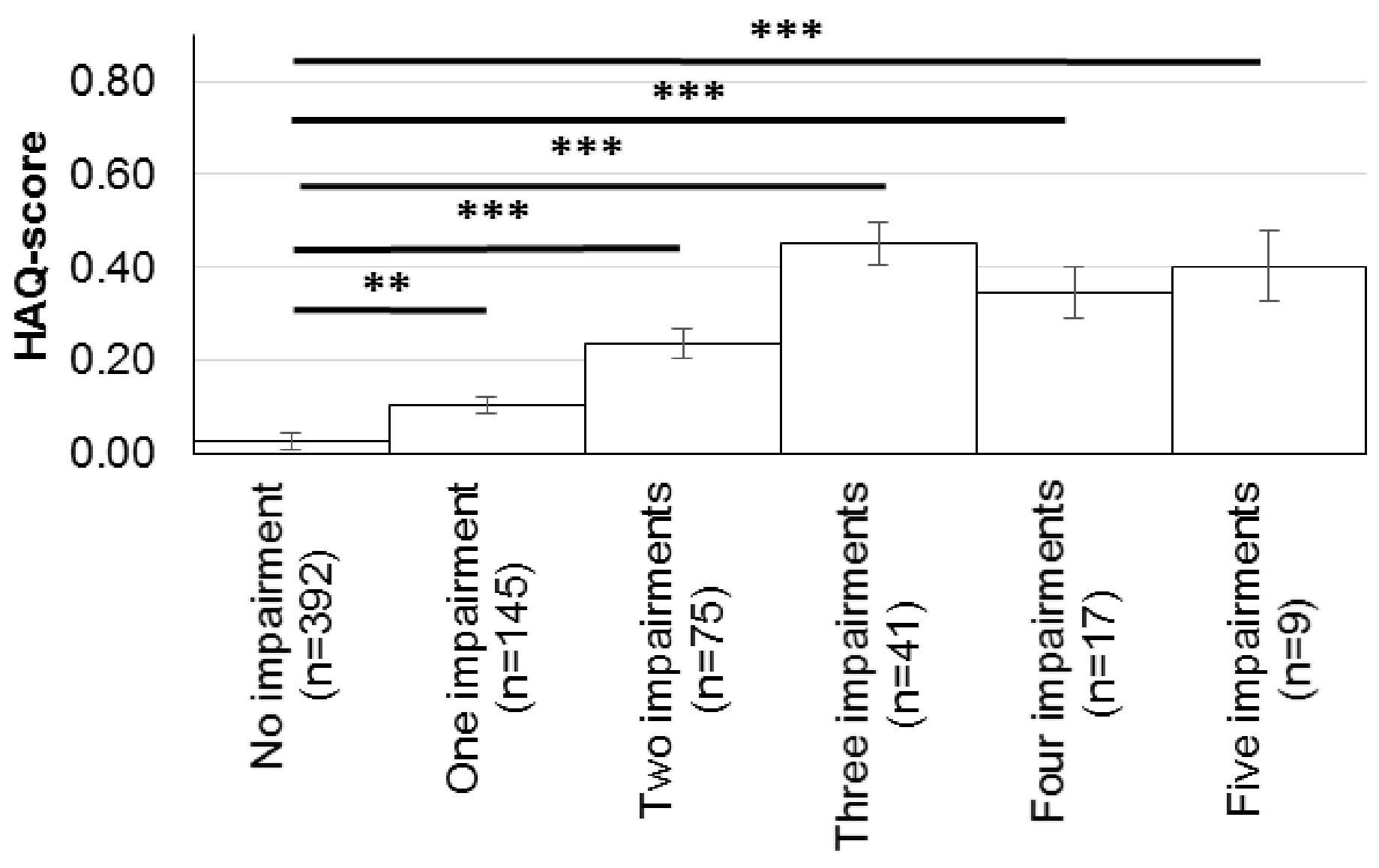

Figure s2. HAQ (Health Assessment Questionnaire)-score in relation to the number of coexisting impairments in controls. The impairments include shoulder stiffness and pain, hand stiffness, hand paraesthesia, finger locking and flexed finger. ${ }^{*} p<0.05 ;{ }^{* *} p<0.01 ; * * * p<0.001 . C T$, carpal tunnel; TF, trigger finger. 


\section{Questionnaire}

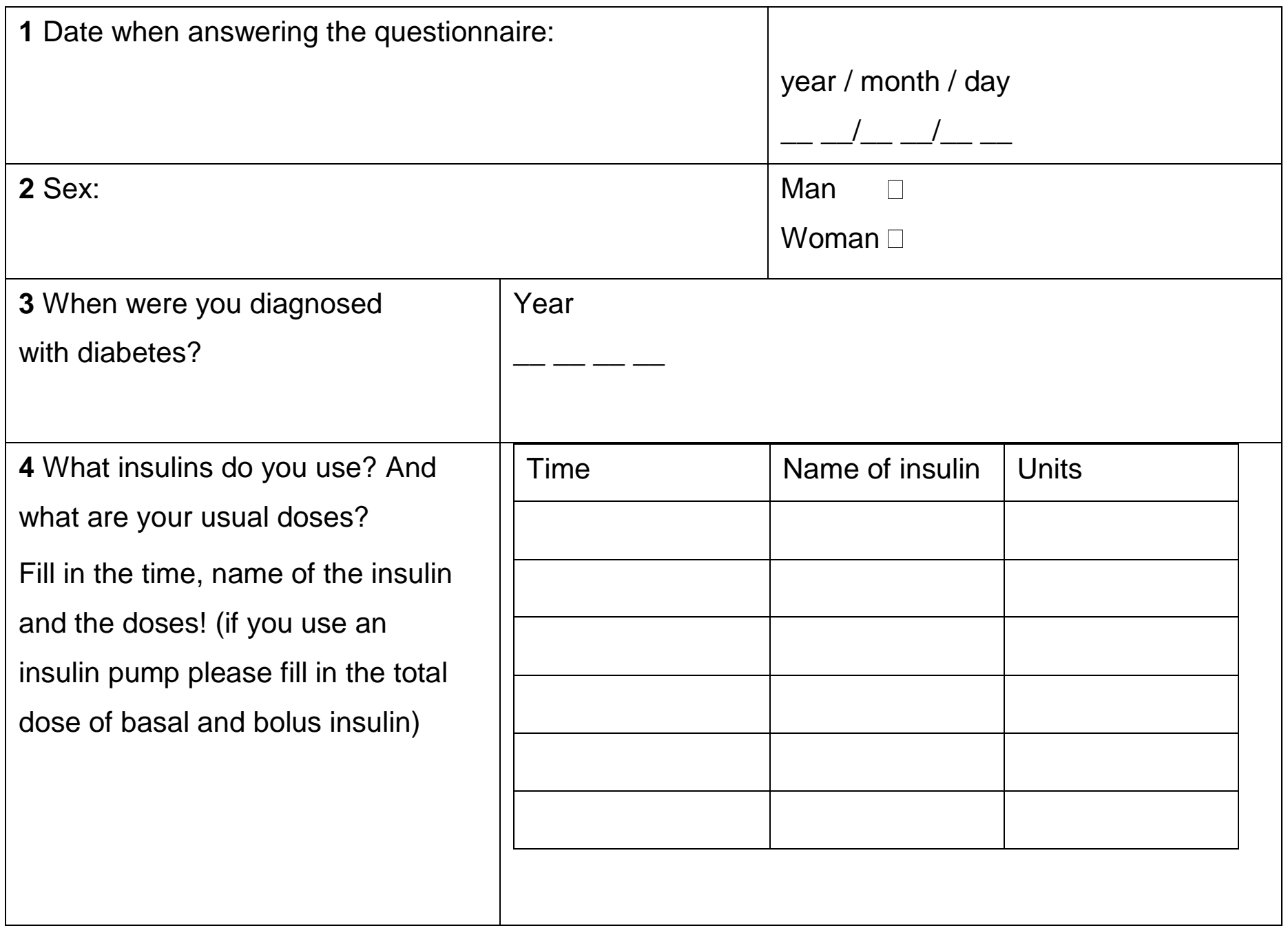


page 2

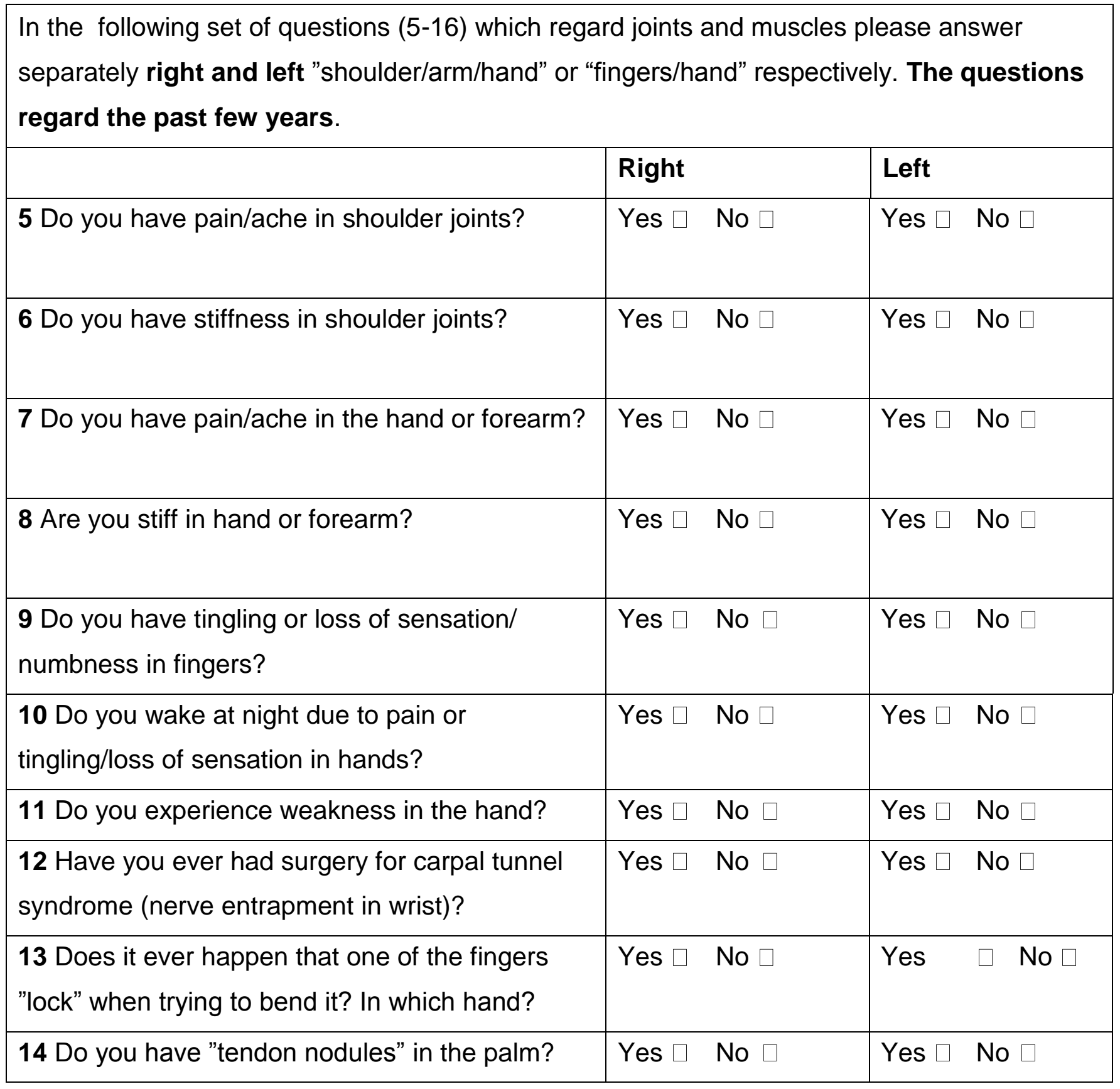




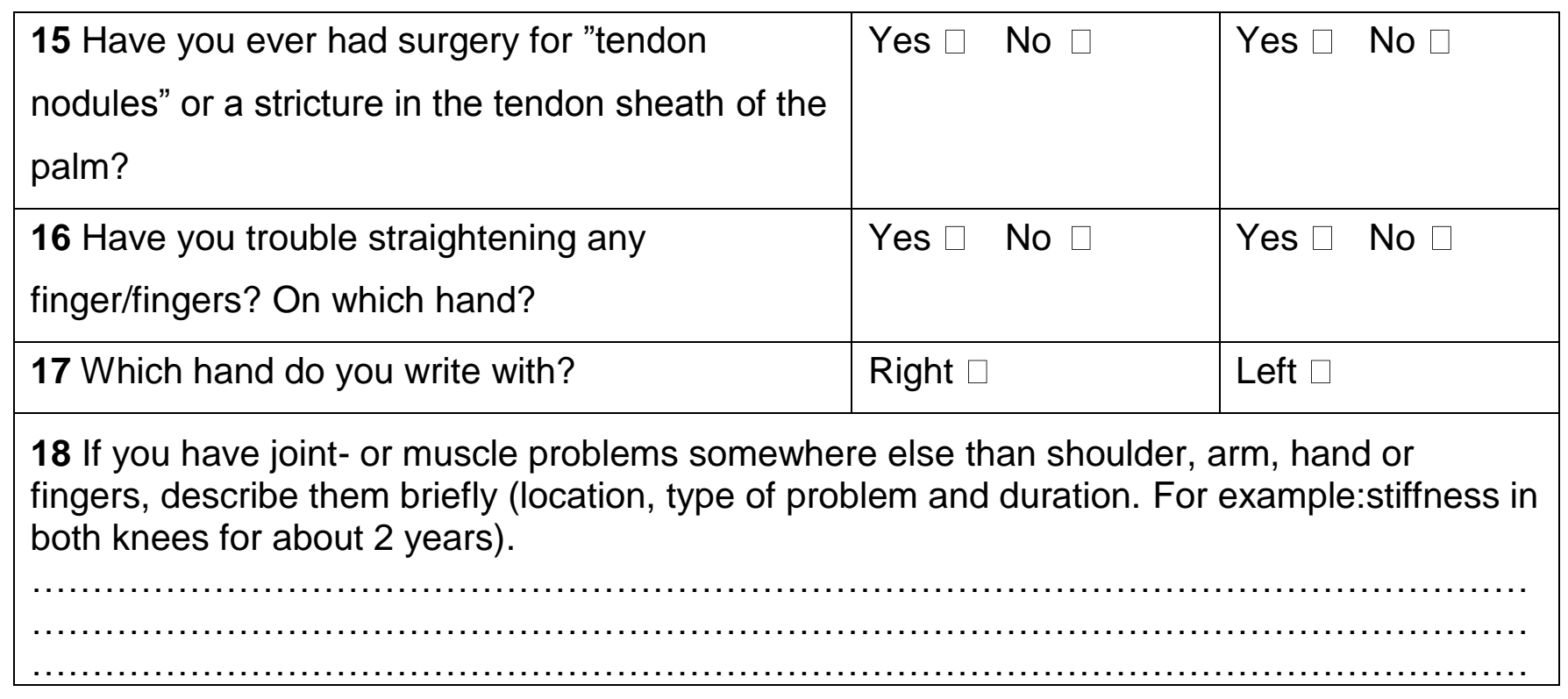


page 3

\begin{tabular}{|c|c|}
\hline $\begin{array}{l}19 \text { Are you prevented in daily activities due to } \\
\text { pain/ache in your joints or muscles? }\end{array}$ & $\begin{array}{l}\text { Not at all } \quad \square \\
\text { A little } \quad \square \\
\text { A lot } \quad \square\end{array}$ \\
\hline $\begin{array}{l}20 \text { Are you prevented in daily activities due to } \\
\text { stiffness from your joints or muscles? }\end{array}$ & $\begin{array}{l}\text { Not at all } \quad \square \\
\text { A little } \quad \square \\
\text { A lot } \quad \square\end{array}$ \\
\hline \multicolumn{2}{|l|}{ General questions } \\
\hline 21 How tall are you? & centimeters \\
\hline $\begin{array}{l}22 \text { How much do you weigh? (with clothes but } \\
\text { without shoes) }\end{array}$ & kilograms \\
\hline 23 What is your occupation? & $\begin{array}{l}\text { Work/employed } \square \quad \text { Full time } \\
\text { Part time } \quad \square \ldots . . \% \text { of full time } \\
\text { On sick leave } \quad \square \quad \text { Full time } \quad \square \\
\text { Part time } \quad \square \ldots \ldots \% \text { of full time } \\
\text { Disability pension } \quad \square \\
\text { Fulltime } \quad \square \text { Part time } \\
\quad \square \ldots . . \% \text { of full time } \\
\text { Jobseeker } \quad \square \\
\text { Student } \quad \square \\
\text { Other alternatives } \quad \square\end{array}$ \\
\hline $\begin{array}{l}24 \text { If you are on sick-leave or have a disability } \\
\text { pension please specify the main cause }\end{array}$ & $\begin{array}{l}\text { Problems from back, muscles or joints } \\
\text { anxiety, stress, depression } \square \\
\text { Diabetes or diabetes complications }\end{array}$ \\
\hline
\end{tabular}




\begin{tabular}{|l|l|}
\hline & $\begin{array}{l}\text { specify } \\
\text { what:................................................... } \\
\text { Other alternatives }\end{array}$ \\
\hline $\begin{array}{l}\text { Answer this question if you are currently } \\
\text { employed! } \\
\mathbf{2 5} \text { Is your work physically demanding? }\end{array}$ & $\begin{array}{l}\text { No, mostly sedentary } \\
\text { Mobile but not physically demanding } \\
\text { Physically demanding }\end{array}$ \\
\hline $\begin{array}{l}\text { Answer this question if you are currently } \\
\text { employed or if you have been employed! } \\
\mathbf{2 6} \text { Through your total occupational life would you } \\
\text { say your work has been physically demanding? }\end{array}$ & $\begin{array}{l}\text { No, mostly sedentary } \\
\text { Physically demanding }\end{array}$ \\
\hline
\end{tabular}


page 4

\begin{tabular}{|c|c|}
\hline 27 Do you drink coffee? & $\begin{array}{l}\text { Never or almost never } \square \\
1-2 \text { cups/week } \square \\
1-2 \text { cups/day } \square \\
>2 \text { cups/day } \square\end{array}$ \\
\hline 28 Do you drink alcohol? & $\begin{array}{l}\text { Never or almost never } \square \\
1-2 \text { times per week } \square \\
>2 \text { times per week but not daily } \square \text { Daily } \square\end{array}$ \\
\hline $\begin{array}{l}29 \text { One standard glass of alcohol corresponds to } \\
50 \mathrm{cl} \text { medium-strong beer, } 33 \mathrm{cl} \text { strong beer, } 15 \\
\mathrm{cl} \text { wine or } 4 \mathrm{cl} \text { liquor. Roughly how many } \\
\text { standard glasses do you drink per week? }\end{array}$ & $\begin{array}{l}\text { None } \square \\
\text { Number }\end{array}$ \\
\hline 30 Do you smoke? & $\begin{array}{l}\text { Yes } \\
\text { number of cigarettes /day: } \\
\text { Yes but not daily/ "party smoker" } \\
\text { No, stopped smoking (year): } \\
\text { No, never smoked } \square\end{array}$ \\
\hline 31 Do you snuff? & $\begin{array}{l}\text { Yes } \\
\text { number of snuff boxes /week: } \\
\text { Yes but not daily } \square \\
\text { No stopped snuffing (year): } \\
\text { No, never snuffed } \square\end{array}$ \\
\hline $\begin{array}{l}32 \text { Physical activity ( } 30 \text { minutes walking or } \\
\text { equivalent, individually adjusted and all forms of } \\
\text { activities count) }\end{array}$ & $\begin{array}{l}\text { Never } \square \\
<1 \text { time/week } \square \\
\text { Regularly } 1-2 \text { times per week } \square\end{array}$ \\
\hline
\end{tabular}




\begin{tabular}{|c|c|}
\hline & $\begin{array}{l}\text { Regularly 3-5 times per week } \square \\
\text { Daily } \square\end{array}$ \\
\hline \multicolumn{2}{|c|}{ Questions on other diseases and medication } \\
\hline $\begin{array}{l}33 \text { Do you have celiac disease (gluten } \\
\text { intolerance)? }\end{array}$ & Yes $\quad \square \quad$ No $\square$ \\
\hline 34 Have you ever sustained a fracture? & 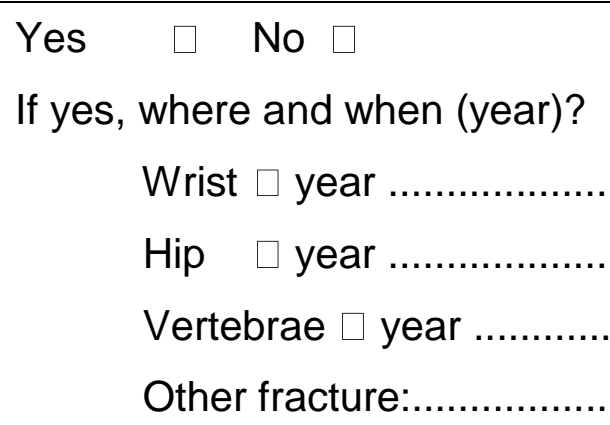 \\
\hline
\end{tabular}




\section{page 5}

\begin{tabular}{|c|c|c|c|c|}
\hline $\begin{array}{l}35 \text { Do you have or have you had angina } \\
\text { pectoris? }\end{array}$ & Yes & $\square$ & No & $\square$ \\
\hline 36 Have you had a heart attack? & Yes & $\square$ & No & $\square$ \\
\hline 37 Have you had a stroke? & Yes & $\square$ & No & $\square$ \\
\hline $\begin{array}{l}38 \text { Have you received laser treatment to any of } \\
\text { your eyes? }\end{array}$ & Yes & $\square$ & No & $\square$ \\
\hline 39 Are you medicating with cortisone pills? & Yes & $\square$ & No & $\square$ \\
\hline $\begin{array}{l}40 \text { Are you on medication against high blood } \\
\text { pressure? }\end{array}$ & Yes & $\square$ & No & $\square$ \\
\hline 41 Are you on lipid lowering medication? & Yes & $\square$ & No & $\square$ \\
\hline $\begin{array}{l}\text { Answer if you are a woman: } \\
42 \text { Do you use birth control pills or hormone pills } \\
\text { due to menopause symptoms? }\end{array}$ & Yes & $\square$ & No & $\square$ \\
\hline $\begin{array}{l}\text { Answer if you are a woman: } \\
43 \text { Are you pregnant? }\end{array}$ & Yes & $\square$ & No & $\square$ \\
\hline
\end{tabular}

